\title{
RONDOM KERK EN ISRAEL
}

\author{
DR. C. J. MANS
}

Israel en die verhouding "Kerk en Israel" is een van die onderwerpe wat deesdae weer feitlik wêreldwye belangstelling geniet. Hierdie artikel wil die aandag vestig op enkele hoofmomente in hierdie denkarbeid van die Kerk oor die wêreld. Volledigheid kon vanselfsprekend nie nagestreef word nie.

\section{HISTORIESE AANTEKENINGE:}

Dit is moontlik om te onderskei tussen twee strome in die geskiedenis van die Kerk se denke ten opsigte van Israel. Die eerste stroom kan ons met Weber ${ }^{1}$ ) die „Christelike Anti-Judaïsme" noem. Hierdie rigting vind ons volgens Weber dan veral by die apologete, die Griekse kerkvaders, in die middeleeuse Jodedialoë, by Luther en in die 19de eeu. Daar is teoloë wat beweer dat hierdie stroom van ,anti-semitisme" oorheersend was in die Kerk se denke oor Israel. Só byvoorbeeld by A. de Kuiper ${ }^{2}$ ) en ook in die ekumeniese denke rondom Kerk en Israel. So beweer Allan T. Davies ${ }^{3}$ ) byvoorbeeld „From the time of the patristic era until virtually the present day, Christian thought - has been infected with an unreasonable and poisonous anti-Judaism". Hy meen dat dit by die Rooms Katolieke denke van voor en selfs na die Tweede Vatikaanse Konsilie voorkom maar ook protes tantse teoloë soos O. Piper, James Daane en selfs K. Barth, kon hulle nie ontwortel aan hierdie „pastristic moorings” nie!

Alhoewel dit waar is dat daar anti-semitiese trekke in die geskiedenis van die Kerk se denke voorkom, is dit ook waar en van veel groter belang, dat daar vanaf die eerste eeu ook 'n ander stroming was wat nie bloot negatief teenoor Israel gestaan het nie.

i. Sommige kerkvaders het die bekering van Israel verwag voor die wederkoms van Christus. Marcion sou nie nodig gehad het om hom daarteen te verweer as dit nie bestaan het nie. Victorinus van Pettau het gemeen dat die heiliges wat met Christus duisend jaar sou regeer, gelowige Jode sal wees. Hiëronymus weet van mense wat die herstel van Juda en Jerusalem verwag het. Hierdie gedagtes het later integrale deel van die leer van die duisendjarige ryk geword.

1) Otto Weber, Grundlagen der Dogmatik, Zweiter Band, Neukirchen 1962, bl. 450 (Gesiteer: Grundlagen II).

2) A. de Kuiper, Israel tussen Zending en Oekumene, Wageningen 1964.

3) Alan T. Davies, The Jews in an Ecumenical Context: A. Critique in Journal of Ecumenical Studies, Vol. 5, no. 3, bl. 490v. (quoted: J.E.S.) (Ons kursivering). 
ii Die beskouings van Luther oor die Jode was inderdaad merkwaardig. In 1523 skrywe hy sy Dasz Jesus Christus ein geborener Jude sei waarin hy praat van dieselfde Bybel wat Jode en Christene het en aandring op 'n gesprek met die Jode. Hy het selfs gemeen dat as hy die misbruike van die Rooms Katolieke Kerk kon opruim, dit sou dien tot die bekering van die Jode. Hy het self ook probeer om enkele Rabbi's te bekeer. Later het hy egter verneem uit Moravia van pogings om Christene tot die Judaissme te verlei. In 1543 volg sy Von den Juden und ihren Luigen wat 'n baie sterk ,,anti-semitiese" inslag het. Luther se uitgangspunt was egter nie rassisties nie maar godsdienstig van aard. Dit was vir hom die grootste sonde om hardnekkig te volhard in die verwerping van die openbaring in Jesus (Christus ${ }^{4}$ ).

iii Bucer het in 1538 saam met enige predikante uit Hessen 'n sogenaamde ,Judenratschlag"5) vir Philips van Hessen opgestel. Hierin word daar betoog dat daar twee moontlikhede ten opsigte van die Jode is: „Wie die Jode onder die Christene wil duld, dink aan die besondere plek wat Israel in God se heilsbedoelinge het en wie hulle wil verdryf kan dit doen om die Christelike godsdiens teen verdere smaad te beskerm". Bucer was in hierdie stuk voorstander van die laaste moontlikheid omdat hy dit as die taak van die owerheid gesien het om die ware godsdiens te handhaaf.

iv. By Calvyn vind ons 'n nugtere standpunt wat nie onder enige verdenking van anti-semitisme kan staan nie. In sy verklaring van Rom .9:26 (en só sal die hele Israel gered word) lees ons byvoorbeeld dat die „,hele Israel” vir hom „die volk van God in die algemeen" is. Die redding van hierdie hele Israel sal egter so geskied ,dat die Jode die eerste plek beklee omdat hulle die eersgeborene in die huisgesin van God is". Op 'n ander plek weer ${ }^{6}$ ): Die Jode is die eerste en die natuurlike erfgename van die evangelie, behalwe vir soverre as wat hulle deur hulle ondankbaarheid as onwaardiges verstoot is, maar dan tog só dat die hemelse seëninge nie in geheel van hierdie volk weggeneem is nie. Die Jode bly die eersgeborene in die huisgesin van God sodat, al hou hulle vol om hardnekkig oorlog te voer teen die evangelie, ons hulle nie mag verag nie omdat God se seën ter wille van die belofte nog op hulle rus.

4) Vergelyk ook Aarne Siirala, Luther and the Jews in Christians, Jews and the Mission of The Church, Publication of the Lutheran World Federation, 1964, bl. 123v.

5) Onder die titel ob Christlicher Oberkeit gepuren muge, das sie die Juden vnder den Christen zuwonen gedulden, vnd wo sie zuidulden, welcher gestalt und maize".

6) Inst. IV, XVI, 14. 
Ander sake wat belangrik is vir Calvyn se siening van die Jode is seker eerstens sy wyse van uitleg van Rom. 9-11. Hy deel nie die chiliastiese uitleggingswyse wat alle heilsgebeure in stiptelike tydelike volgorde wil sien nie. By die „ten dele" $\epsilon$ n "totdat" van Rom. 11:25 merk hy op: ek dink nie dit het eenvoudig betrekking op tyd of getal nie, maar op wyse, op manier, tot 'n mate. ,Totdat' druk ook nie progressie of tydsverloop uit nie maar beteken dieselfde ding asof Paulus wil sê: ,Dat die volheid van die heidene . . . ". "Volheid" dui vir Calvyn ,'n groot getal" aan terwyl Rom. 9:26 se „hele Israel” die „hele volk van God" aandui.

Tweedens moet ons wys op hoe Calvyn kennis van God moontlik ag. By sy uitleg van 1 Petr. 1:21 sê hy dat ons slegs deur Jesus Christus vir God kan ken. „Daarom is al ons kennis van God buite Christus om soos 'n afgrond wat onmiddellik al ons gedagtes verswelg. Ons het 'n duidelike bewys hiervan in die Turke en die Jode wat in plaas van God, hulle eie drome aanbid". Hy was immers "van die begin van die wêreld aan die uitverkorenes voorgehou as die voorwerp van hulle geloof en vertroue" $)$. Met ander woorde daar kan geen sprake van wees dat die Jode kennis van God kan hê sonder „bekering”, dit wil sê aanvaarding van Jesus Christus in die geloof as die Messias van Israel nie. Hierdie aspek van Calvyn se denke is van die grootste belang want dit word myns insiens veral in die „ekumeniese gesprek" met Israel buite rekening gelaat.

' $n$ Derde saak wat in verband met Calvyn geopper moet word is die uitverkiesing van God wat uitverkiesing in Jesus Christus is (byvoorbeeld na aanleiding van Ef. 1:4) $)^{8}$. Hy is die uitverkiesende God self (na aanleiding van Joh. 13:18) ${ }^{\circ}$ ) of soos Niesel ${ }^{10}$ ) dit stel: Hy is die „Erkenntnisgrund" en die „Realgrund" in Calvyn se uitverkiesingsleer.

v. Die 17de en 18de eeuse protestantisme het hom ook met Israel besig gehou. Gomarus en Voetius het byvoorbeeld die terugkeer van Israel na die beloofde land as deel van die heilsverwagting afgewys. In hierdie tyd het verskillende persone en groepe gemeen dat die „openbaring van die Antichris", die "volksbekering van die Jode", die „prediking van die evangelie aan die hele wêreld" soms ook "die terugkeer van die Jode na Palestina" tot die besondere voortekens van Christus se koms gereken moet word.

7) Inst. 11, VI, 4.

8) Sien Inst. 111, XXIV, 5.

9) Sien Inst. I11, XXII, 7.

10) Wilhelm Niesel, Die Theologie Calvins, München 1957, Zweite Auflage, bl. 166. 
vi. Dit is ook belangrik om Schleiermacher se beskouing kortliks na te gaan omdat sy denke oor Israel en die Ou Testament, invloed op die meer resente uitsprake oor die verhouding Kerk en Israel het. Schleiermacher handel in sy Ueber die Religion: Reden an die Gebildeten unter ihren Verächteren, onder die vyfde toespraak, „Die Religionen" ook kortliks oor die Christelike godsdiens en die Judaĩsme. Eersgenoemde is vir hom die "hoogste stadium" van die godsdiens, terwyl laasgenoemde 'n "laere trap" is wat bowendien ,lankal reeds dood is". Hulle wat hierdie afgestorwe godsdiens vandag nog aanhang is soos mense wat „langs 'n onverganklike mummie sit om sy heengaan en bejammerenswaardige erfenis te beween". Die Joodse Godsdiens was hoegenaamd nie 'n voorloper van die Christelike godsdiens nie. Daarom kon hy in Der Christliche Glaube, paragraaf 12 dan ook sê dat die Christendom wel 'n besondere historiese verband met die Joodse Godsdiens het maar „wat sy historiese bestaan en doel betref, staan die Christendom tot die jodedom in dieselfde verhouding as tot die heidendom".

Schleiermacher het hierdie uitgangspunt deurgetrek na sy Jeer oor die Heilige Skrif. In paragraaf 27 verklaar hy dat die „Ou Testament 'n oorbodige gesag vir die Dogmatiek is" en dat evangeliese leerstukke alleen gestaaf hoef te word deur die evangeliese belydenisskrifte of die Nuwe Testament.

Schleiermacher het 'n sterk invloed uitgeoefen op die „moderne eksistensialistiese teologie" se beskouing oor die Ou Testament. Rengstorf ${ }^{11}$ ) beweer met reg "that in modern existentialistic theology Judaism is being met half-way in a most generous fashion in its denial ... of Christianity's claim to exclusive contınuity with pre-Christian Israel in the history of revelation". Die „ontmitologisering" van die Nuwe Testament het wye belangstelling in Joodse kringe geniet. Hulle het immers nog altyd beweer dat die Christeiike leer oor die inkarnasie, die opstanding en die hemelvaart van Jesus van Nasaret, „absurd” is!

vii. Soos hierbo reeds hier en daar deurgeskemer het, beklee Israel veral 'n besondere plek in die chiliastiese voorstellings oor die duisendjarige ryk. Hierdie tydperk sal een wees waarin die Jode saam met Christus sal regeer in die herstelde aardse Jerusalem. As koning van hierdie ryk is Christus ook die koning van Israel.

11) K. H. Rengstorf, The Place of the Jew in The Theology of the Christian Mission in Christians, Jews and the Mission of the Church, Publication of the Lutheran World Federation, 1964 (?), bl. 78. 
Volgens die chiliaste is daar in die Bybel allerlei beloftes gemaak oor die status van Israel soos byvoorbeeld die herstel van sy staat sodat die totstandkoming van die staat, Israel, vir hulle die begin van die verwerkliking van die beloftes in die Bybel is. Hierdie volk is vir hulle 'n volk met 'n besondere plek in God se heilswerk en beklee dit 'n uitsonderlike plek onder die volke van die wêreld. Van die baie beloftes wat aan Israel gegee is, moet die volgende nog vervul word: die heropbou van die heilige land en die bekering van die hele volk Israel. Die grond vir dit alles is God self en die onveranderlikheid van Sy beloftes ${ }^{12}$ ).

Die kritiek van die kerk op die chiliastiese voorstellings oor Israel kan soos volg opgesom word:

1. Agter die chiliastiese voorstellings en die leer van die Kerk oor Israel lê daar twee verskillende skrifbeskouings.

2. Daar bestaan 'n diepgaande kloof tussen die eksegetiese praktyk van die chiliasme en dié van die reformatore soos hierbo by Calvyn se eksegese van Rom. 9-11 aangetoon is.

3. Die Kerk het hierdie beskouing oor die toekoms van Israel in twee belydenisskrifte veroordeel: In die Lutherse Augsburgse Konfessie lui dit: „Met groot eenstemmigheid veroordeel die kerke by ons ook die ander wat nou die Joodse denkbeelde versprei dat voor die opstanding van die dode die vromes 'n wêreldse koninkryk sal bewoon waar die goddelose verdruk word". In die Calvinistiese Tweede Helvetiese Konfessie lui dit: ${ }^{13}$ ) „Ons veroordeel verder die Joodse drome dat voor die oordeelsdag 'n goue tydperk op die aarde sal aanbreek en die vromes 'n wêreldse koninkryk sal bewoon, met vernietiging van hulle goddelose vyande. Want die ware Evangelie ... en die Apostoliese leer . . . is lank reeds neergelê en stel dit anders voor".

Dit is só dat die Kerk se belydenis oor Israel skraal is. Maar tog dui sy denke, wat gewoonlik ,polemiese denke en belydenis" was, die rigting aan waarin die Kerk en Israel gewerk het ${ }^{14}$ ).

12) 'n Volledige uiteensetting van die chiliastiese voorstellings oor Israel met kritiek daarop, is beskikbaar in die ongepubliseerde Verslag van die Raad vir die Arbeid onder Israel aan die Algemene Kerkvergadering van die Nederduitsch Hervormde Kerk van Afrika van 1964, Bylae M. (Gesiteer: Bylae $\mathbf{M}$ ). Ons het hier en elders ruimskoots van hierdie waardevolle werkstuk gebruik gemaak.

13) Hoofstuk 11, pw. 4.

14) Sien Byle $M$, bl. 7-11. 


\section{BYBELSE GEGEWENS:}

Voordat ons oorgaan om die meer resente denke oor die verhouding van Kerk en Israel te behandel is dit nodig om eers aandag te skenk aan A) Die volk Israel; B) Die begrippe „Jood" en Israel in die Nuwe Testament.

\section{A. DIE VOLK ISRAEL ${ }^{15}$ ).}

Die volk Israel het 'n historiese werklikheid geword op die landdag van Sigem (Jos. 24) as 'n twaalf-stamverband. Die deurslaggewende eenheidsfaktor was sakraal van aard terwyl ander faktore soos taal en lewenswyse 'n minder belangrike rol gespeel het. Die eenheidsfaktor was die gemeenskaplike verering van Jahwe (wat eintlik hierdie twaalf-stammeverband tot volk geroep het) met 'n sentrale heiligdom en die belydenis van die gemeenskaplike tradisie van die heilsdade van Jahwe in die geskiedenis. Hierdie salkrale binding het sy voortgang ook onder die konings gehad wat hulle gesag ontleen het aan hulle verkiesing deur Jahwe. Onder die konings het die volk Israel 'n staat onder ander state geword met sy eie politieke grense, ens.

$\mathrm{Na}$ die skeuring van die twaalf-stamme ryk, is die naam gebruik vir die noordelike ryk, waar die politieke betekenis van die naam oorheersend was. As aanduiding van die sakrale eenheid (Juda en Israel) het die benaming sy voortgang gehad in religieuse uitdrukkings soos "Heilige van Israel”, „Lig van Israel", ens.

Na die ballingskap is die benaming gebruik vir die „oorblyfsel" van die ou suidelike ryk. Onder hierdie oorblyfsel wat hulle geskaar het rondom die heiligdom en die bindende karakter van die wet, het die benaming „Israel" 'n sterk teokratiese inslag gekry.

In die na-eksiliese tyd kom die naam „Jode” voor as benaming vir die stam Juda (waarvan „Jode" afgelei is) en sy woonplek. Die nie-Jode het dit gebruik ter aanduiding van Israeliete. Dit is deur die Jode self ook gebruik in verdrae en amptelike stukke. Dit was veral die gebruik by die Jodedom in die Makkabeërtyd. Maar in stukke met 'n religieuse strekking word die benaming "Jode" nie deur hulle self gebruik nie maar konsekwent die naam „Israel”. Die benaming "Israel” is onbekend by heidense skrywers wat met die begrip "Jode" volks- én religieuse verbondenheid aangedui het.

15) Sien ook Bylae $M$, bls. 2 en 3 waarvan hier gebruik gemaak is en Theologisches Wörterbuch aum Neuen Testaments, Dritter Band, bls. 356-394. (Gesiteer: ThWNT). 
In die na-eksiliese tyd het die naam „Israel” by die Jode self eintlik 'n belydenis geword waarmee hulle hul verbondenheid aan die Israel-tradisie wou aandui maar terselfdertyd ook hulle eiesoortigheid onder die ander volke van die wêreld wou onderstreep. Hierdie gebruik van die naam „Israel" bevat ook die Joodse aanspraak op die beloftes wat aan die Israel van die verlede gegee is.

\section{B. DIE BEGRIPPE „JOOD,, EN ISRAEL IN DIE NUWE TESTA- MENT}

\section{JOOD/JODE:}

By die synoptici kry ons dieselfde gebruik van die benamings as in die Palestynse taalgebruik. „Jode” is die benaming vir die Joodse volk in die mond van nie-Jode of deur die Jode self in hulle omgang met nie-Jode, of wanneer die evangelis sy lesers oor bepaalde Joodse gebruike wil inlig. 'n Voorbeeld hiervan is die benaming „Koning van die Jode" deur die wyse manne (Mtt. 2:2) en deur Pilatus (Mtt. 27:11 (par.)).

Alhoewel dieselfde gebruik ook by Joh. en Hand. voorkom, dien die benaming hier ook om die teenstanders van Jesus en Sy gemeente aan te dui. In hierdie spraakgebruik word die kloof wat tussen die Jode en die Christendom rondom Christus ontstaan het, duidelik. Hierdie kloof het sy oorsprong in die Joodse afwysing van Jesus as die Messias. „Jode” word aanduiding vir hulle wat Jesus afwys as Messias. Jode wat in die Kerk opgeneem is, word ook wel Jode genoem, maar „die Jode” met lidwoord dui die teenstanders van die Kerk aan.

Paulus gebruik die benaming „Jood" op 'n besondere manier. Eerstens gebruik hy die woord dikwels in die enkelvoud wat origens nie voorkom nie behalwe wanneer 'n skrywer wou aandui dat ' $n$ bepaalde persoon 'n Jood is. Net so maak Paulus dikwels gebruik van die begrippe „Jood" en „Jode" sonder lidwoord. Ook hierdie gebruik is origens ongewoon. Hieruit is dit ook reeds duidelik dat Paulus onder „Jode” 'n bepaalde tipe, 'n geestelike religieuse grootheid verstaan.

Paulus gebruik die benaming "Jode" ook in die gewone betekenis byvoorbeeld in 1 Thes. 1:14-16. Die Jode vervolg hom en die gemeente van die Here; hulle het ook „die Here Jesus 
en hulle eie profete gedood"16). Die vermelding van die profete dui egter ook hier op iets „Uberzeitlich-Typisch” in Paulus se gebruik van die benaming.

Die "abstrakte" gebruik van die naam is duidelik in Rom. 2:28 en 29 waar die ware Jood gestel word teenoor die een wat dit net na die uiterlike is. Hy wat "Jood is in die verborgene" word onderskei van hom wat "Jood is in die openbaar". Egte Jood, „Jood in die openbaar" is hy wat die wet ken en dit onderhou (Rom. 2:17). "Jood" is dan egter nie meer in die eerste plek aanduiding van 'n bepaalde persoon nie, maar het 'n religieuse begrip geword. Dit is ook duidelik uit Gal. 2:13v: daar is "Jode" wat Christene is, maar aan die uiterlike wet gebonde wil bly. Paulus reken homself onder diegene wat van nature (dit wil sê van geboorte) Jode is, maar wat die regverdiging nie uit die werke van die wet nie, maar alleen deur die geloof in Jesus Christus verkry het (Gal. 2:15-17).

\section{SAMEVATTEND:}

(a) Paulus gebruik die benaming „Jood" nie ongekwalifiseerd nie.

(b) Die benaming bevat soms die element van volksverbondenheid.

(c) Die religieuse element staan by Paulus voorop. Negatief dui dit op alle afwysing van Christus en positief op wetsgebondenheid.

(d) Daar is "Jode" in die Kerk maar die tipiese Jood is die een wat Christus en Sy genadige regverdiging van sondaars afwys ter wille van selfregverdiging deur die wet.

\section{ISRAEL:}

Oor die benaming "Israel" in die Nuwe Testament kortliks die volgende:

i By die synoptici dui "Israel" die besondere wese van Israel as volk van God aan. Dit is byvoorbeeld duidelik in die Nuwe Testamentiese begrippe soos „God van Israel (Mtt. 15:31; Luk. $1: 68)$, „Koning van Israel”, ens.

Die benaming word egter nie in die synoptiese evangelies aangewend om hulle wat in Jesus Christus glo aan te dui nie.

16) Markus Barth. Was Paul an Anti-Semite?, J.E.S., Volume 5, 1968, bl. 98 oordeel asvolg oor 1 Thes. 1:14-66: ,These verses may indeed be called a sample of that anti-Semitism which is sometimes found not only among Gentiles but in worse form in the hearts and upon the lips of desperate Jews". 
ii. By Johannes kom die tydsomvattende karakter van die benaming Israel na vore. Dit wil die Israel van alle tye insluit. Hy gebruik egter ook nie hierdie benaming ter aanduiding van die Christusgelowiges nie.

iii. In Hand. word "Israel" in die eerste en "Jode" in die tweede helfte van die boek gebruik. Die benaming "Israel" word ook hier vir die volk van God in tydsomvattende betekenis gebruik. In Hand. 13:23 (met sy beklemtoning dat „God vir Israel uit die nageslag van hierdie man (Dawid), volgens die belofte, Jesus as Verlosser verwek het") kom die gedagte na vore dat die Israel wat die belofte ontvang het en die Israel wat die vervulling van die belofte ontvang het, identies is. Hierdie Israel, dit wil sê, die Israel van die belofte én die Israel van die vervulling, is die valk van God.

In Hand. tree daar egter 'n breuk in die godsvolk aan die lig. Dit is eerstens te wyte aan die prediking van die gemeente na die uitstorting van die Heilige Gees wat tot Israel gerig was. As 'n mens let op die inhoud van Petrus se preek in Hand. 2 (of ook Hiand. $3: 12-26 ; 5: 29-32 ; 10: 34-43 ; 13: 16-41)$ dan is dit duidelik dat hierdie prediking "Missions-oder Bekerungspredikt" ${ }^{17}$ ) was wat die bekering van die Jode en proseliete voor oog gehad het (En uit Hand. 7:51 is dit ook duidelik hoe vlymskerp die taal van hierdie prediking kon wees!). Die Jesus wat hulle (die Jode) gekruisig het, is "die Here en Christus" (2:36) wat God vir Israel verwek het volgens die beloftes (10:23) in Wie daar vir Israel bekering en vergifnis van sondes is (2:37-39). Die eerste bekeerlinge kom dan ook uit Israel sodat in hulle „die volk van die belofte" en "die volk van die vervulling" een en dieselfde Israel is.

Die breuk in die godsvolk is egter ook en veral aan Israel te danke: dit is ook Israel (,volke van Israel") wat saam met heidene teen die Kind, Jesus vergader (4:27). Só onstaan daar rondom die opgestane Jesus wat deur die gemeente as „Here en Christus" (dit wil sê „beloofde Messias") verkondig is 'n spanning tussen Israel en Israel, Israel en Kerk. En ondanks watter redes daar nou nog vir hierdie spanning genoem kan word, staan dit vas dat hierdie spanning sentreer rondom een vraag, „die waarheidsvraag": Wie is Jesus van Nasaret?

iv. Dit was egter veral Paulus wat voluit aan hierdie spanning aandag gegee het. By Paulus word dit duidelik waarin hierdie spanning bestaan en waarin dit nie bestaan nie. Dit is daarom nodig dat ons breedvoeriger aandag sal gee aan Paulus en dan veral aan Rom. 9-11.

17) Bo Reike, Glauben und Leben der Urgemeinde, Zürich 1957, bl. 44. 
(a) Israel het 'n onvervreembare gekwalifiseerde verlede: In 1 Thes. 2:13v het Paulus dit te doen met 'n vyandige Jodendom. In Rom. 9-11 skemer egter 'n ewe gevaarlike farisese heidenchristendom deur wat alles kan vertroebel. Wat Paulus hier (veral Rom. 11) bestry was in hoofsaak nog altyd die uitgangspunt van die "Christelike anti-Judaīsme"18). Die argument lui só: Omdat Israel vir Christus en daarom sy eie uitverkiesing verwerp het, is die heiden-Christendom nou die besitters van die heil en die uitverkore volk van God. Hulle het die erfenis van Israel, wat hy verlaat het, in besit geneem.

Paulus wys dit af. Hy weet dat die Messias van Israel wat deur Sy eie volk verwerp is, deur die heidene angeneem is. Dit is egter vir hom 'n gebeurtenis wat reeds in die Ou Testament as kenmerk van die verwagte heilstyd uitgewys is (Vergelyk Rom. 10:19v en Rom. 9:25v met Jes. 10:22v; 65:1; Dt. 32:31; Hos. 2:23). Dit is nie só dat die heilstyd uit twee stadiums van 'n vuurpyl of uit twee tydvakke bestaan wat kronologies op mekaar volg nie: die eerste sou dan begin met die uitverkiesing van Israel en eindig met Israel se verwerping van sy Messias en die tweede sou dan begin met die uitverkiesing van die heidene. Daar bestaan vir Paulus en die res van die Nuwe Testament nie 'n heiden-Christendom wat op sigself uitverkies is nie. Die Nuwe Testament weet wel van buitestaanders wat ook na die groot maaltyd uitgenooi is (Luk. 14:23). Die Nuwe Testament ken dus, net soos van die Jode, ook geen vanselfprekende aanspraak wat die heidene op Christus het nie. God se genadige uitverkiesing van die heidene is 'n „Hinzu-erwählung"1,9) soos Paulus dit duidelik in Rom. 11 stel.

Israel het dus 'n ,gekwalifiseerde verlede" wat nie weggeredeneer kan word nie (Rom. 11:29). Hy het 'n onloënbare voorrang, 'n primaat oor die heidene van alle tye want aan hom, en nie aan die heidene nie, ,behoort die aanneming tot kinders en die heerlikheid en die verbonde en die wetgewing en die erediens en die beloftes en die vaders uit wie die Christus na die vlees is" (Rom. 9:4 en 5). Israel besit nou eenmaal hierdie primaat.

(b) Die uitverkiesing van Israel: Maar wie is Israel? Nie almal is Israel wat uit Israel is nie (9:6). Hulle is nie kinders van God net maar omdat hulle nageslag van Abraham is nie want ,nageslag" is slegs die kinders van die belofte (9:8). Daar moet dus onderskei word tussen „Israel na die vlees" en "Israel na die belofte". Slegs aan laasgenoemde is die beloftes gegee en hulle is diegene wat in Jesus Christus glo.

18) Só O. Weber, Grundlagen 11, bl. 540 .

19) 0 . Weber, Grundlagen 11, bl. 540. 
Die feit dat daar 'n Israel ,na die vlees' en 'n ,Israel van die belofte" is, berus egter op die genadige uitverkiesing van God (9:18 saam met 9:20). Dit is egter nie iets nuuts nie want Israel se bestaan was nog altyd afhanklik van die vrye verkiesing van God. Daar was die belofte aan Sara (9:9) en die verkiesing, Jakob bo die skynbaar meer deugsame Esau (9:10-13). Daarsonder sou Israel nie wees wat hy was en is nie. Daar is God se woorde: „Ek sal barmhartig wees oor wie Ek barmhartig wil wees en My ontferm oor wie Ek My wil ontferm" (9:15 met Eks. 33:19). Sonder hierdie God wat só is en só handel sou Israel ook nie kon wees wat hy is nie. So hang dit dan nie af van die een "wat wil of van die een wat loop nie, maar van God wat barmhartig is" (9:16). Israel kon kla oor die heidene wat skielik na vore tree. Paulus se egter dat dit berus by die uitver. kiesende God self. Hy is soewerein vry (9:20); Hy rig Hom tot hulle aan wie Hy Sy barmhartigheid wil bewys. Hy het egter ook „voorwerpe van toorn" wat Hy "tot oneer" gemaak het $(9: 21)$. Hulle is ook Sy werk al is hulle "vir die verderf toeberei" (9:22). En God het hulle „met groot lankmoedigheid" verdra juis om ,die rykdom van Sy heerlikheid oor die voorwerpe van barmhartigheid" bekend te maak (9:22 en 23). Hierdie "voorwerpe van barmhartigheid" het Hy geroep "nie alleen uit die Jode nie maar ook uit die heidene" (9:24).

Israel het dus vir Paulus nog altyd in die lig van die vryheid van God se uitverkiesing gestaan. Hy is nie uit homself wat Hy is nie, maar uit God. Dit bewys Paulus uit die Ou Testament.

Om hierdie rede is Israel in sy aantoonbare gestalte nie identies met die uitverkore Israel nie. Die genade van die uitverkiesende God was immers nie net vry vir Israel nie, maar ook vry van Israel (Ismael en Isak; Jakob en Esau - 9:9-13).

(c) Israel verwerp sy uitverkiesing: Israel leef egter nie uit sy goddelike bestemming nie. In plaas van te lewe van die genade van God, het hy verkies om sy bestemming te bereik langs die weg van ,die werke van die wet”. Maar Hy het „die wet van die geregtigheid nie bereik nie" omdat hy ,die geregtigheid wat uit die geloof" (in Jesus Christus) is, verwerp het (9:30 en 31). „Hulle het hul gestamp teen die steen van aanstoot" (9:32 en 33). Hulle het die verkondiging van die geloofsregverdigheid in Christus "gehoor" (10:18) en hulle kon dit selfs ook „verstaan" (10: 19v), maar hulle kon die belydende antwoord (soos in 10:9 en 10) nie uitspreek nie. En omdat hulle hierdie Christus in Wie al God se beloftes ,,ja en amen" is (2 Kor. 1:20), verwerp het, is hulle skuldig voor God, ook aan hulle eie verworpenheid. 
Nou wys Weber ${ }^{20}$ ) daarop dat dit vir Paulus hier nie gaan om 'n ,afgeslote verlede" nie, maar dat hy die situasie in die heilstyd in gedagte het. By Paulus is hierdie situasie egter nooit iets wat losstaan van die verbond nie. Die "nuwe" verbond is vir Paulus die "oue”. Tussen die "nuwe” en die „oue" staan Christus. In Hom het ons dit nie met 'n ,ander" god nie, maar met dieselfde God wat Israel tot godsvolk gemaak het, te doen. As Israel vir Jesus Christus verwerp, verwerp hy daarmee vir Hom deur Wie hy uitverkies is en verwerp hy ewe-eens die grond van sy bestaan. Israel se verwerping ,ist das Nichterwăhlen seiner eigenen Erwählung"21).

Maar Paulus wil dit beklemtoon dat God, ondanks Israel se ongeloof, hom nie verstoot nie (11:1). Daarvoor is daar ook 'n bewys naamlik die ,oorblyfsel (ooreenkomstig die verkiesing van die genade" - 11:5) wat reeds in die Kerk is (soos Paulus self en andere) soos in die tyd van Elia reeds bepaal is (11:2-5). Hierdie "oorblyfsel" is nie meer verworpe nie, maar uitverkies. Hulle is die eerstelinge van die ganse Israel. Daarom kan daar slegs in „,begrensde" sin van Israel se verwerping gepraat word.

(d) Die verwerping van Israel is die heil van die heidene: Verder betoog Paulus dat die val van Israel die heil van die heidene geword het (Rom. 11:11) en dat daarin reeds die belofte van Israel se opname gegee is. God gebruik die val van Israel (soos die verharding van Farao) in sy heilsplan. Sy val word ,die rykdom van die wêreld" (11:12). Sy Messias word die Christus van die heidene. Maar ook dit is reeds in die Ou Testament voorsien: Die wortel van Isaĩ sal daar wees, en Hy wat opstaan om oor die nasies te heers, op Hom sal die nasies hoop" (Rom. 15:12 en Jes. 11:10).

(e) Die toekoms van Israel: Israel se verwerping van sy Messias en daarop van sy uitverkiesing, is egter nie finaal nie. Dit sal op indirekte wyse ook betekenis vir homself hê. Langs die omweg van wat met die heidene gebeur - só hoop Paulus sal hulle ,jaloers” gemaak word (11 en 15). God wil dat „die volheid van die heidene" aanleiding sal wees tot "die volheid van Israel" (11:25 en 26), met ander woorde tot daardie gebeurtenis waarin nie net 'n „oorblyfsel” van Israel gered sal wees nie maar „die hele Israel" (11:27). Só word ook selfs die heidene wat glo instrument in God se heilsplan waarin die Israel-vanSy-verkiesing ewig 'n plek het.

20) O. Weber, Grundiagen 11, bl. 542.

21) O. Weber, a.w., 1 bl. 542. 
(f) Die verhouding Israel en Heiden-Christene: Israel, die godsvolk, is die mak olyfboom (11:24) waarop takke van 'n wilde olyfboom (dit is die heidene) ingeënt is (11:24) en waarvan sommige van sy "natuurlike takke" afgebreek is maar nie almal nie. Die natuurlike takke wat afgebreek is, is deur ,ongeloof" afgebreek (11:20), maar ,as hulle nie in die ongeloof bly nie sal hulle ingeënt word" (11:23) want dieselfde God wat in Sy barmhartigheid sommige takke uitgebreek het, ,is magtig om hulle weer in te ent" (11:23). En soos hierdie boom nou daar staan met sommige van sy takke afgebreek en die takke van 'n wilde olyfboom daarop ingeënt, is hy Israel. Hierdie boom met die wilde takke daarop ingeënt en sommige van sy takke afgebreek vervang nie die Israel van die belofte nie, maar is self die Israel van die belofte, die volk van die uitverkiesing. Hy is uitverkies in die belofte wat vervul is, in die beloofde Messias wat in Jesus van Nasaret gekom het.

Dit is dus duidelik: God het die grense van Sy volk laat uitdy om ook die heidene te omvat. Paulus bring dit nogeens ter sprake in Ef. 2:11-22: „die heidene en onbesnedenes was vervreemd van die burgerskap van Israel en vreemdeling ten aansien van die verbonde van die belofte, sonder hoop en sonder God in die wêreld" (2:12), maar nou het hulle "wat vroeër ver was (dit is die heidene) naby gekom deur die bloed van Christus" (2:13). Hy het „die middelmuur van skeiding afgebreek” en ,albei een gemaak" (2:14) want hulle word deur die kruis van Christus in een liggaam met God versoen. Nou is die heidene „medeburgers van die heiliges en huisgenote van God" (2:19). Hulle, die heidene, was immers nooit uitgesluit uit die verkiesing van Israel nie (Hand. 2:39; 13:46, 47; Gal. 3:8, 9).

Maar 'n mens kan en moet dit ook in 'n ander lig sien. Hierdie Israel, die mak olyfboom met sy natuurlike takke (= die oorblyfsel van Israel wat glo) en die ingeënte takke ( $=$ die heidene wat glo) is die "Israel van God" (Gal. 6:16), die Kerk, „die gemeente wat die Seun van God uit die ganse menslike geslag (uit Jode en heidene dus) deur Sy Gees en Woord in die eenheid van die ware geloof, van die begin van die wêreld af tot aan die einde toe vergader, beskerm en onderhou"222). Binne die Kerk is daar volkome vrede tussen die natuurlike takke en die ingeënte takke van die wilde olyfboom, tussen Jood en heiden. Hier is daar nie 'n probleem „Kerk en Israel” nie.

22) Heidelbergse Kategismus, vraag en antwoord 54. Vergelyk ook Nederlandse Geloofsbelydenis Art. XXVII. 
Maar rondom hierdie boom wat die Israel van die belofte is, lê daar nog die afgebreekte natuurlike takke, Israel in sy verharding wat in die ongeloof self wil bly staan; hulle vir wie Christus ,'n steen van aanstoot en 'n rots van struikeling is" (Rom. 9:33). Oor hulle kan die olyfboom, wat nog steeds die littekens van hulle verwydering dra, nie anders as eindelose bewoënheid ken nie, want só soos hierdie boom nou is, is hy die Israel van die belofte, maar nog lank nie in volledige gestalte nie, want ook hierdie uitgebreekte takke is Israel al is hy die Israel van die verharding! Hy moet nog deur die God van alle barmhartigheid teruggeënt word - en dit sal geskied waar en wanneer en soos dit die soewerein vrye God van alle barmhartigheid behaag. Met die oog gevestig op hierdie gebeurtenis wag, werk en bid die Kerk (= die Israel van God - Gal. 6:16). Eers wanneer dit gebeur sal die gestalte van die Kerk volledig wees; dan wanneer hy bestaan uit "die volheid van die heidene" en ,die volheid van Israel". Die spanning tussen Israel en Israel, Kerk eri Israel sal dus bestaan so lank dit God behaag.

(g) „Hoe" sal die Kerk werk, waak en bid op Israel se terugkoms? Maar "hoe" sal die Kerk nou werk, waak en bid met die oog op Israel van die verharding te terugkoms?

Daar word myns insiens, twee belangrike aanduidings hiervan in Rom. 9-11 gegee.

i. Die Kerk moet Israel ,jaloers maak” (11:11 en 15). Wat Paulus presies daaronder verstaan het, is nie meer duidelik nie. Is dit die Kerk in die totaliteit van sy bestaan as ,liggaam van Christus"? Dit kan so lyk.

ii. In Rom. $10: 14 \mathrm{v}$ bring Paulus die instrumentarium van die Heilige Gees na vore. „Elkeen wat die Naam van die Here aanroep, sal gered word". Maar hoe kan 'n mens Hom aanroep in Wie jy nie "glo" nie? En hoe kan 'n mens glo in Hom van Wie jy nog nie "gehoor" het nie? En hoe kan jy hoor as daar nie iemand is wat „preek" nie? Die „geloof" is immers uit die „gehoor" en ,die gehoor is deur die Woord van God." Dit is die weg van God met alle mense - ook Israel. Só word mens deur God self "bekeer" en hulle wat deur God die Heilige Gees bekeer is het kennis van God, ook daardie kennis as Sy genadige geskenk, dat Jesus Christus die Here is. Dit is immers duidelik aan Paulus se eie lewe. Ook hy kon die Messias van Israel eers in Jesus Christus ken ná sy bekering.

Die weg van die Kerk met die Israel van die verharding blyk dan die weg van die verkondiging van Jesus Christus (1 Petr. 2:9 en 10) te wees - volgehoue verkondiging met die geduld om te wag op God en met die gebed vir Israel in die hart en die mond. 


\section{SAMEVATTING:}

Nadat ons die belangrikste Nuwe Testamentiese getuienis in hierdie verband nagegaan het, blyk nou die volgende: (a) daar is kontinuïteit tussen Kerk en Israel maar (b) die kontinuïteit is "gebroke" en (c) die gebroke kontinuiteit is tydelik.

(a) Die kontinuïteit tussen Kerk en Israel bestaan in:

i. Die uitverkiesing van Israel.

ii. Die uitverkiesing van Israel is egter uitverkiesing in sy beloofde Messias, Jesus Christus.

iii. Die uitverkiesing van die heidene is ingesluit in die verkiesing van Israel.

iv. Dat Christus na die vlees uit die geslag van Dawid is beteken nie dat Israel 'n vanselfsprekende aanspraak op Hom het nie. Al is die Messias uit Israel is Hy nooit Israel se „besit” nie. Die Christus is God se vrye genade aan Jood én heiden.

v. Die belydenis dat God se uitverkiesing in Jesus Christus, die beloofde Messias van Israel, geskied, sluit die verkiesing van die Kerk in. Die Kerk is "die besnydenis", het Abraham as "vader" (Rom. 4) en hy gaan terug op die beloftes wat aan Abraham gegee is (byvoorbeeld Gal. 3:7; 4:21 ens.).

vi. Die Kerk bestaan nie in sy eie sfeer teenoor dié van Israel nie, maar juis in dié van Israel. Sy godsdiens is nie 'n "nuwe" godsdiens nie maar juis voortsetting van die „oue”. Sy Heer is immers niemand anders as die Messias van Israel nie! Die saligheid is uit die Jode.

vii. Juis omdat sy Heer die Messias van Israel is, is die Ou Testament vir die Kerk nie maar net interessante materiaal uit die geskiedenis van die godsdienstige, nie maar net 'n soort praeparatio evangelii nie, maar deel van die Bybel, Woord van God.

(b) Maar dit is onmiskenbaar ook gebroke kontinuïteit, want Israel het sy Messias verwerp.

(c) Die gebrokenheid van hierdie kontinuïteit is egter nie finaal nie maar tydelik. Israel sal op God se tyd gered word.

(d) Omdat die Kerk dit verwag het van die begin af, het hy met sy verkondiging van Jesus Christus in die tempel van Jerusalem begin, maar ook in elke stad en dorp in die vreemde het Paulus byvoorbeeld altyd by die Jode in die sinagoge begin. Netso sal die Kerk in sy verkondiging van Christus nou ook nie by Israel mag verbygaan nie. 


\section{DIE MEER RESENTE DENKE OOR KERK EN ISRAEL:}

Onder hierdie hoof wil ons ons hoofsaaklik bepaal by die denke van Karl Barth, die Tweede Vatikaanse Konsilie, die Wêreldraad van Kerke, die Lutheren World Federation, Die Kerkwet van die Nederduitsch Hervormde Kerk van Afrika.

\section{A KARL BARTH ${ }^{23}$ ):}

Barth behandel die verhouding „Kerk en Israel" in die se wende hoofstuk van sy Kirchliche Dogmatik ${ }^{24}$ ). Die opskrif van hierdie hoofstuk is „Gottes Gnadenwahl". Nadat Barth in paragraaf 32 gehandel het oor „Die Aufgabe rechter Lehre von Gottes Gnadenwahl” en in paragraaf 33 ,Die Erwählung Jesu Christi” behandel in paragraaf 34 „Die Erwählung der Gemeinde”. Onder hierdie laaste paragraaf kom die verhouding van Kerk en Israel ter sprake.

Barth behandel die probleem „Kerk en Israel” dus onder sy leer van die uitverkiesing. Barth se leer oor hierdie verhouding kan dan ook net as integrale deel van sy leer van die uitverkiesing begryp word.

Die hoofmomente van Barth se leer van die uitverkiesing is die volgende:

1. Eerstens is die uitverkiesing ,das ganze Evangelium, das Evangelium in nuce"25). Die uiteensetting van die uitverkiesingsleer moet dus die karakter van evangelieverkondiging aanneem.

2. Oor die uitverkiesing kan nie buite die openbaring en sonder die geloof gepraat word nie. Met ander woorde wanneer ons praat oor die uitverkiesing moet ons oë gevestig wees ,auf den Namen Jesus Christus und auf die in ihm verwirklichte Existenz und Geschichte des Volkes, dessen Anfang und Ende im Geheimnis seines Names beschlossen ist"26). Dit gaan in die uitverkiesing nie om 'n abstrakte God nie, maar om God in Christus. Dit gaan ook nie om 'n abstrakte mens nie, maar om die Mens Jesus Christus. In Jesus Christus, waaragtig God en waaragtig mens, val die „der erwählende Gott” en „der erwählte Mensch" saam²7).

3. Die opskrif van paragraaf 33 „Die Erwählung Jesu Christi” het dus ' $n$ dubbele betekenis: dit is uitverkiesing wat deur Hom-

23) Sien ook Bylae $M$ bl. 11-17 waarvan ons ruim gebruik gemaak het. Ons meen die hand van Prof. B. J. Engelbrecht in hierdie stuk te sien.

24) Karl Barth, Kirchliche Dogmatik, Die Lehre von Gott, Zweiter Band. Sweiter Halb Band Zürich 1948, bl. 1-563 (Gesiteer: KD 11²).

25) $\mathrm{KD} 11^{2}$, bl. 13 .

26) KD 112, bls. 62 en 63 .

2i) KD 112, bls. 63. 
self geskied en dit is uitverkiesing wat aan Hom voltrek is. Hy is uitverkiesende God en uitverkiesende mens.

4. Jesus Christus is uitverkiesende God. In Hom het ons dit „unmittelbar mit dem erwählenden Gott selbst zu tun . . ." "28). Dit gaan in die uitverkiesing dus nie om 'n Deus nudus absconditus nie (soos by Calvyn) maar om die Deus revelatus wat as sodanig ook die Deus absconditus is ${ }^{29}$. As ons dus nog van 'n decretum wil praat, moet dit van 'n decretum concretum wees ${ }^{30}$ ). Daarom is die „Kompliment der Erwählung der Glaube ${ }^{31}$ ) en niks anders nie.

5. Jesus Christus is die uitverkore mens. As ons volgens Ef. 1:14 ,in Hom" uitverkies is, dan kan dit slegs beteken ,,in seiner Person, in seinem Willen, in seinem eigenen göttlichen Erwăhlen" ${ }^{32}$ ). Dat Hy die uitverkore mens is, kom veral na vore in Joh. 17:24, Luk. 9:35; 23:35. „Hy is alleen deur God se genade die Seun van God"33) en „soos Hy Christus geword (uit genade) het, word ons Christene" ${ }^{34}$ ). In Hom het God ,die verwerping en dood van die mens, Sy eie saak gemaak" ${ }^{35}$ ). In Hom, in die dood van Hom in Wie die mens uitverkies is, is „hy as sondaar werklik dood" ${ }^{36}$ ). God het Hom ook egter opgewek en bevestig daarmee dat Christus, Sy eie Seun, die uitverkore mens is.

6. In hierdie $\sin$ is die uitverkiesing praedestinato gemina. In Jesus Christus blyk dit inderdaad dat God se wil 'n „Ja" en 'n "Nee" bevat ${ }^{37}$ ). In die plaasvervangende lyding van Jesus Christus word dit duidelik dat God in Jesus Christus self die „Nee" „die Verwerfung, die Verdammnis und ten Tod" wat die mense toekom, kies en $\mathrm{dra}^{38}$ ). In soverre daar dus in die uitverkiesing 'n „Nee" weerklink is dit in elkgeval 'n „Nee" wat nie die mens tref nie ${ }^{39}$ ). Terselfdertyd word dit ook in die dood van Christus duidelik dat God in Hom Sy „Ja” „die Erwählung, die Seligkeit und das Leben" skenk. Daarom beteken geloof in die uitverkiesing van God: "Glaube an die Nicht-Verwerfung des Menschen, Nicht-Glaube an seine Verwerfung"40).

\footnotetext{
28) KD $11^{2}$, bls. 115 .

29) KD $11^{2}$, bls. 119 .

30) KD 112, bl. 108 .

31) KD 112, bl. 121

32) KD 112, bl. 125 .

33) KD 112, bl. 129.

34) KD $1^{2}$, bl. 127 .

35) KD 112, bl. 133 .

36) KD 112, bi. 134

37) KD 112, bl. 176

38) KD 112, bl. 177 .

39) KD 112, bl. 182 .

40) KD 112, bl. 182 .
} 
7. Hulle wat Jesus Christus glo, is die „voorwerp van God se uitverkiesing"'11). Konkreet bestaan die uitverkiesing van hulle wat ,in Hom" uitverkies is ,in ihrem Glaube an ihn"42). Daarom is die geloof die komplement van die uitverkiesing want deur die geloof in Jesus Christus skenk God ons die uitverkiesing, die saligheid en die lewe ${ }^{43}$ ). Dit is wat Ef. 1:4 bedoel met „,in Hom uitverkies" wees van ewigheid af.

8. In paragraaf 34 handel Barth oor „Die Erwählung der Gemeinde". Hulle wat "in Hom" uitverkies is, is eerstens die gemeente en dan die enkeling. Oor laasgenoemde handel Barth in paragraaf 35 en is nie hier ter sake nie.

i. Maar wat is die gemeente? Barth antwoord: „Die Gemeinde ist diejenige menschliche Gemeinschaft, die vorläufig in besondere Weise die natürliche und geschichtliche Umgebung des Menschen Jesus bildet". Die „besonderheid" van die gemeente bestaan in sy getuienis aan die wêreld en sy oproep tot geloof in Jesus Christus. Haar „voorlopigheid" bestaan daarin dat sy bo haarself uitwys na die "gemeenskap van alle mense" ${ }^{44}$ ).

ii. Maar wie is Jesus in Sy verhouding tot die gemeente? $\mathrm{Hy}$ is die „Messias van Israel” en $\mathrm{Hy}$ is die „Hoof en Heer van die Kerk wat uit Jode en heidene bestaan" en Hy is „als Beides (dit wil sê Messias van Israel en Hoof en Heer van die Kerk) unauflöslich Einer"45).

iii. Die gemeente en sy uitverkiesing stem ooreen met hierdie „eenheid en tweeheid" van sy Hoof en Heer, Jesus Christus. Hy bestaan uit die „Volk Israel (,,in der ganzen Ausdehnung seiner Geschichte in Vergangenheit und Zukunft, ante et post Christum natum!) und . . . die Kirche aus Juden und Heiden (von ihrer Offenbarung an Pfingsten bis zu ihrer Vollendung durch die Widerkunft Christi)"46). En soos sy Hoof en Heer ,als Beides unauflöslich Einer" is, is ook die gemeente een in die "unaufhebbar Beides: Israel und Kirche"17). Juis as Kerk is die gemeente Israel en juis as Israel is sy Kerk.

iv. Israel, die eerste „lid" van die uitverkore gemeente is nou vir Barth die volgende:
41) KD 112, bl. 136.
42) KD 112, bl. 135 .
43) KD 112, bl. 182 .
44) KD 112, bl. 216.
45) KD 112, bl. 218 .
10) KD $11^{2}$, bl. 218.
ii) KD 112, bls. 218 en 219. 
(a) Israel is die uitverkore volk van God in Jesus Christus (want daar is geen uitverkiesing buite Hom nie). Jesus Christus het na die vlees uit Israel voortgekom. Hy is die ,gekruisigde Messias van Israel" en deur Sy opstanding ook die geopenbaarde Messias van Israel" 48 ). Israel is "die verborge oorsprong van die Kerk" ${ }^{49}$ ). In Israel is die „präexistente Leben der Kirche" geleë ${ }^{50}$ ).

(b) Israel is egter ,als solches und im Ganzen seiner Erwählung nicht gehorsam, sondern ungehorsam". Hy verwerp sy Messias; hy weier om "met die belydenis van die Kerk in te stem", om "sy diens in die een uitverkore gemeente te aanvaar". Hy bou en onderhou (,trots der Bestätigung des Abschlusses seiner Geshichte durch die Untergang Jerusalems!') die Synagoge $\left.^{51}\right)$. En tog kan die ongeloof van Israel niks daaraan verander dat hy „objektiv und faktisch auch in dieser sinnwidrigen Stellung neben und auszer der Kirche das Volk seines gekommen und gekreuzigten Messias und also des heimlichen (ihm immer noch verborgenen) Herrn der Kirche ist" ${ }^{32}$ ).

(c) Onder i. hierbo het ons gesien dat die "besonderheid" van die uitverkore gemeente (waarvan Israel die eerste "lid" is) die diens van getuie-vir-die-wêreld is. Ook dit kan Israel deur die verwerping van sy uitverkiesing in Jesus Christus nie ongedaan maak nie! Waarin bestaan die besondere getuienis van Israel nou? Die antwoord wat Barth gee lui so: Die gemeente (= Israel plus die Kerk) moet „,der Spiegel” vir die wêreld wees van die dinge wat in die voorbeeld van die uitverkiesing (dit is Jesus Christus) gerealiseer en openbaar is. Die gemeente moet dus die dubbele gebeure van die uitverkiesing van Jesus Christus en deur Jesus Christus (uitverkiesende God en uitverkore mens) caarstel en hierdie dubbele gebeure is God se gerig en God se erbarming of beter: God se gerig in sy erbarming en God se erbarming in Sy gerig.

Israel se besondere diens binne die geheel van die gemeente van die uitverkiesing is dan dat hy "Spiegel des Gerichts" moet wees, dit wil sê van daardie gerig wat God van die mense weggeneem het deur dit self in Jesus Christus te dra ${ }^{53}$ ). Israel kan slegs ,das nackte, blanke Gericht Gottes darstellen, nur die widersetzlichkeit und das ihr folgende Elend des Menschen, nur das Urteil und die strafe, die Gott in seinem Erbarmen für sich selber gewählt, damit sie uns nicht treffen möchten . . " ${ }^{54}$ ).

48) KD 112, bl. 218.

49) KD 112, bl. 219 .

so) KD 112, bl. 234 .

51) KD 112, bl. 229.

52) KD 112, bl. 230.

53) KD 112, bl. 227.

54) KD 112, bl. 230 . 
In die Israel-gestalte van die gemeente kom veral twee dinge na vore:

Eerstens . . . „was Gott für sich erwählt . . ." naamlik „... . kein gehorsames, sondern ein widersetzliches Volk, . . . kein Volk, das ihm etwas zu geben hätte sondern ein solches das alles von ihm zu empfangen hat"55). Israel toon aan ons "den menschlichen Grund diese göttlichen Leidens" naamlik die „Unfähigkeit, Unwilligkeit und Unwürdigkeit" is van Israel, is waar van alle mense ${ }^{57}$ ), ook van die Kerk. „Die Kirche weisz . . . nur insofern um des Menschen Elend als auch Israel - als Spiegel des göttlichen Gerichts - in ihr lebt". As die Kerk op die een of ander wyse van sy „Israelitiese oorsprong vervreem raak dan sal hierdie gebeure hom vroeër of later daarin wreek dat die Kerk se „Zeugnis von des Menschen Elend und dann bestimmt auch das von Jesu Christi Kreuz und heilsamen Leiden in ihrer Mitte seine kraft verliert und lasz sie darum im selben Masz Beides auch die Welt schuldig bleibt"'58.

Daarom is dit vir die gemeente nodig dat „Israel in ihrer Mitte Weiterlebe"59). Hy het sy Messias verwerp, hom verset teen die genade. Daarmee het hy homself veroordeel, maar daarmee het hy nie opgehou om die volk van die opgestane Christus te wees nie, die gemeente van God te dien en sy getuienis waarvoor hy uitverkies is af te lê nie: Al kan hy nie bely „Er ist aufgestanden!" nie, „musz sie doch das, ,Er ist nicht hier!' um so deutlicher aussprechen”. Hy getuig van die „Finsternis” wat oor die wêreld toegesak het toe Jesus gesterf het. Hy getuig „vom Seufzen der Kreatur das das Charakteristikum des Kosmos ist, in dem und für den Jesus sterben muszte". En daarin word Israel se onmag cuidelik. Hy kan homself „verdammen, belasten und bestrüben”, maar hy kan niks daarvan verander ,dasz auch ihm ein Erlöser lebt"') $)$. In hom, die verworpene word egter „den Adressaten des Evangeliums" sigbaar. Hy bly in die gesigsveld van die uitverkiesing staan as die representant van die mense vir soverre hulle „der göttlichen Erwählung bedürftig sind"'11). Hier word die mens sigbaar vir wie God se selfontlediging nodig is. Só word Israel, weliswaar indirek en onwetend, maar tog werklike getuie van God se genadige uitverkiesing.

(d) Barth stel dit dat Israel geen ,besondere Bestimmung und Zukunft neben und auszerhalb der Kirche" het wat hy

55) KD 112, bls. 227 en 229.

(:) KD 112, bl. 227.

57) KD $11^{2}$, bl. 219

58) KD 112, bl. 227.

59) KD 112, bl. 287.

60) KD 112, bls. 290 en 291 .

в1) $\mathrm{KD} 11^{2}$, bl. 504. 
dan "neben und auszerhalb der Kirche" kan realiseer nie $^{62}$ ). Die Kerk (as versameling van Jode en heidene) is egter op grond van sy uitverkiesing ,die offenbarte Bestimmung Israels"63). Wanneer Israel nou aan sy verkiesing gehoorsaam word sal dit die volgende beteken: Eerstens dat sy besondere getuienis van God se gerig tot „Unterton" van die getuienis van die Kerk sal word en só, deur die stem van die Kerk gedra, bedek (in die beste sin van die woord), gedemp in die "Loblied" van ciie een uitverkore gemeente (= Israel en Kerk) opgeneem sal word". En dit sal Israel binne die Kerk se besondere eer altyd wees om die Kerk altyd weer daarmee te vertroos en te vermaan deur te wys op die ,erbarming van God in Sy gerig wat oor die mense gegaan het en om "die kruis van sy Heer" as sy enigste verwagting altyd voor oë te hou $\left.{ }^{64}\right)$.

Verder: as Israel aan sy uitverkiesing gehoorsaam word sal sy getuienis binne die Kerk ook eskatologiese betekenis hê: dit sal in die Kerk en in die wêreld voortdurend herinner aan die „Erbarmens Gottes, im Vergehen, im Tod, in der Beseitigung des Alten". Die „oue”, die mens wat hom teen God verset, is aan die verbygaan, ja, moet verbygaan om met God in vrede die onverganklike lewe te ontvang ${ }^{65}$ ). Só sal Israel dan getuig van die laaste onmag van die bose wat in Jesus Christus oorwin is aan die kruis. Dit alles egter nêrens en nooit buite en sonder Christus nie.

Die volk Israel word by Barth op hierdie wyse, netsoos sy leer van die uitverkiesing, evangelieverkondiging, 'n stuk Christusverkondiging.

v. Die tweede "lid" van God se uitverkore ,gemeente" is vir Barth die Kerk. Wat is die Kerk?

(a) Die Kerk as hierdie tweede ,lid" van God se gemeente bestaan uit "Juden und Heiden (von ihrer Offenbarung an Pfingsten bis zu ihrer Vollendung durch die Widerkunft Christi").

(b) Die verband van die tweede lid van die uitverkiesde gemeente van God met die eerste lid,, Israel, is dat "der Herr der Kirche ... der Messias Israels" is ${ }^{96}$ ). Verder is die Kerk "die offenbarte Bestimmung Israels" al is dit waar dat Israel "die heimliche Ursprung der Kirche" is ${ }^{6 i}$ ). Israel en Kerk staan egter nie in 'n starre naas-mekaar nie. Rom. 9 toon immers aan dat God self van tyd tot tyd deur Sy uitverkiesing van "Israel" „Kerk" gemaak het en daar sodoende 'n ,präexistendte Leben der

62) KD $11^{2}$, bl. 229

63) $\mathrm{KD} \mathrm{112}$, bl. 219.

64) KD 112, bl. 229.

65) KD 112, bl. 286.

66) KD 112, bl. 218

6i) KD 112, bl. 219. 
Kirche in Israel" was wat weliswaar uitsluitlik bestaan het uit die lig van die komende Messias wat „,vorläufig” op die geskiedenis van Israel geval het sonder om die karakter van hierdie volk se geskiedenis in geheel te verander ${ }^{68}$ ).

(c) Die Kerk moet ook "Spiegel" wees en wel van dit wat in die uitverkiesing deur én van die Voorbeeld, Jesus Christus, vir ons geskied het. Die Kerk moet dan spieëlbeeld van God se erbarming wees; die spieëlbeeld van wat God van onbekwame, onwillige en ongenoorsame mense maak $^{69}$ ). Die Kerklike gestalte van die gemeente laat sigbaar word „was Gott für den Menschen wählt, in dem er ihn in seiner ewigen Gnadenwald zur gemeinschaft mit ihm selber erwählt. Er wählt für den Menschen seine ... sich schenkende Liebe. Er Wählt aus dem Schatz seines eigenen Wesens Gerechtigkeit und Heiligkeit, Frieden und Freude, Leben und Seligkeit . . . Er wählt also für den Menschen den Abglanz seiner eigenen Herrlichkeit" ${ }^{70}$ ). Waar die Israelitiese gestalte van die gemeente vir die gemeente dus die verbygaan van die ou wederstrewige mens aandui, daar wys die Kerklike gestalte van die gemeente op die nuwe, komende en blywende eksistensie-vorm van die gemeenskap tussen God en die mense.

Die kerklike gestalte van die gemeente staan in dieselfde verhouding tot sy Israelitiese gestalte as die opstanding van Jesus Christus tot Sy kruisiging, as God se erbarming tot Sy gerig. Daaruit volg dat die Kerk ouer is as die pinksterwonder en die daaropvolgende versameling van die Kerk uit Jode en heidene. Dit het reeds in Israel bestaan. Die Kerk is dus die doel en die grond van die uitverkiesing, ook reeds van die uitverkiesing van Israel ${ }^{71}$ ).

In die kerklike gestalte van die gemeente betree die gemeente sy „vermittelnde Funktion als die vorlăufige Umgebung des Menschen Jesus, in ihrer Sendung der Welt gegenüber"'2). Aan die ganse wêreld moet die Kerk „Gottes siegreiches Erbarmen" verkondig en die wêreld oproep tot die geloof in Christus.

vi. Hoe moet die Kerk sy taak ten opsigte van die Jode, die synagoge, Israel sien?

Barth het ook hiervoor belangrike opmerkings in sy Kirchliche Dogmatik ${ }^{73}$ ) gemaak. Hy behandel dit in paragraaf 72 (Der Hellige Geist und die Sendung der Christlichen Gemeinde), punt

68) KD 112, bl. 234.

(i) $\mathrm{KD} \mathrm{112}$, bl. 231 .

70) KD 112, bl. 232 .

71) KD 112, bl. 233

i2) KD 112, bl. 233 .

?) KD IV/3 (2 Hälfte) bl. 1005-1007. 
4. onder die opskrif (Der Dienst der Gemeinde).

Barth se gedagtegang is soos volg:

(a) Die Gemeente se besonderheid bestaan in sy getuienis voor die wêreld en sy oproep tot geloof in Jesus Christus. Aan die hele wêreld (,,auch dem ganzen Israel selbst!) moet die Kerk Gottes siegreiches Erbarmen" verkondigit).

(b) Hoe moet die Kerk nou hierdie ,Zeugendienst" ten opsigte van die Jode, die synagoge of Israel uitvoer? Barth gee sy antwoord in 'n ekskurs aan die einde van sy uiteensetting van wat onder ,sending" verstaan moet word. Hy doen dit egter nie omdat hy dink dat die begrip ,sending" aanduiding is van die „Zeugendienst" wat die Kerk aan Israel verskuldig is nie, maar juis omdat dit in die Kerk se verhouding tot Israel nie om „,sending" kan gaan nie. Die begrip „Judenmission" is 'n ongelukkige begrip wat die egte Jood slegs beledigend kan vind. Dit is nie wat die Kerk aan Israel verskuldig is nie. As Paulus ,'n Jood vir die Jode" wil wees, is dit nie net iets wat slegs „,formal, sondern sachlich toto coelo anderes" is as wanneer hy vir die Grieke 'n Griek wil wees' ${ }^{76}$ ).

(c) Twee sake moet in die oog gehou word:

i. In die verkondiging van die Kerk aan die Synagoge kan dit nie gaan om die verkondiging van „die ware geloof" teenoor ,'n valse geloof", „die ware God" teenoor „'n valse god" nie. Die God Wie se werk en Woord die Kerk aan die wêreld (en dus ook aan Israel) moet verkondig, is die God van Israel tot vandag toe. Die Kerk is immers opgeneem in Israel "se uitverkiesing en roeping en lewe in die gemeenskap met sy Koning. „Wie konnte sie Israel ,missioneren' wollen? Israel is tot vandag toe "das natürlich-geschichtliche Monument der Liebe und Treue Gottes . . . der einzige . . . auszerbiblische Gottesbeweis". Wat kan ons Israel leer, wat ons nie veeleer by hom moet leer nie? ${ }^{\text {76 }}$ ).

ii. Maar daarby kom 'n ander (maar definitief ,als Zweiter'), 'n ,erschutterende Tatsache": Israel het sy uitverkiesing en roeping verwerp toe hy sy Messias verwerp het. Sy verworpe Messias het toe "Heiland van die wêreld" en ons Koning geword terwyl langs die Kerk die synagoge bly bestaan het as die „Orga . nisation einer noch und in eine . . . lehr gewordene Zukunft eilenden, einer noch immer ungetrosteten, an ein noch immer unerfülltes Wort sich klammerende Menschheit". Só het Israel spie ëlbeeld geword van die "gnadenlosen Existenz",

74) KD 112, bl. 235.

75) KD IV' $3 / 2$, bl. 1005 .

i6) KDIV $3 / 2$, bl. 1005-1006. 
spieëlbeeld van dieselfde bestaan „... der wir arme Heiden ohne das, was in der Person jenes einen Juden für uns geschehen und uns offenbar ist, rettunglos verfallen wärren".

Hier is niks meer „zu missionieren” nie! Hier kan ons nog slegs God se gerig in Sy liefde aanskou en in hoogste deelname vrees.

Informasiegesprekke kan nog gevoer word. Maar „wat kan die evangelie deur mense aan mense bedien, daar nog uitrig waar dit reeds - en dit nie toevallig, terloops nie - maar prinsipieel, a priori en dus menslik gesproke sonder moontlikheid van revisie, verwerp is?" Is daar 'n ander weg as die weg wat God met Paulus "die Obstinatisten aller Jude" gevolg het - 'n direkte ingrype deur God dus? Só het Paulus self die bekering van Israel as geheel as 'n eskatologiese gebeurtenis gesien (Rom. $11: 15,25 \mathrm{v})$.

iii. Maar beteken dit nou dat die Kerk ontslae is van sy ,Zeugendienst" ten opsigte van Israel? Nee, maar die Kerk moet "Israel jaloers maak" soos Paulus dit stel in Rom. 11:11, 14. En dit bestaan daarin: „Sie (dit is die Kerk) muszte sie (dit is Israel) in ihrer eigenen Existenz als Gemeinde des ihr als Retter der Welt offenbar geworden Jüdenkönigs vor das Faktum des Ereignis geworden Trostes des erfüllten Wortes Gottes stellen, sie ihrerseits mit dem Monument der freien, nun aber nicht verschmähten s ondern dankbar bejahten und ergriffenen Erwählung, Berufung und Gnade Gottes konfrontieren". Die Kerk moet poog om Hom wat hulle verwerp het" „lieb, begehrenswert, einleuchtend zu machen ... als ihr wirklich gekommenen Messias". En so moet die Kerk Israel ,oproep om hom met haar, as Sy volk en sodoende met Homself te verenig. Geen ander funksie dus nie as net hierdie oproep van die ,vor den Augen auch der Juden authentisch gelebte Leben der Gemeinde in seiner Ganzheit" sal Israel jaloers kan maak nie.

Die Kerk was egter nog nooit hierdie oproep nie en is dit ook nou nog nie! Dit het die Kerk aan Israel skuldig gebly!

iv. Die ekumeniese beweging "ly vandag swaarder onder die afwesigheid van Israel as onder dié van Rome of Moskou". Die Kerk moet saam „met die synagoge lewe maar dan nie soos die dwase in hul harte sê, soos met 'n ander godsdiens of konfessie nie, maar as met die wortel waaruit hy self voortgekom het". Dit wil die Kerk egter nie doen nie en daarom hang hierdie onopgelosde probleem soos 'n skaduwee oor al die Kerk se werk op die sendingveld! 


\section{B. DIE TWEEDE VATIKAANSE KONSILIE:}

Op die 28ste November 1965 het die Tweede Vatikaanse Konsilie 'n „Verklaring oor die houding van die Kerk ten opsigte van die nie-Christelike Godsdienste" afgekondig. Die Verklaring bestaan uit ongeveer 450 woorde. Ongelukkig kon ons die hand nie lê op 'n volledige teks van die Verklaring nie en moes ons terugval op sitate wat ons by verskillende skrywers gevind het ${ }^{77}$ ).

In die Verklaring word die volgende gestel:

1. Daar bestaan ,'n geestelike verbondenheid van die Kerk met die nakomelinge van Abraham". Israel is die uitverkore volk en in 'n tussensin word gesê dat God in Sy barmhartigheid met hierdie volk die ou verbond wou sluit en dat die Kerk deur (per, en nie ab nie) hierdie volk die openbaring van die Ou Testament ontvang het.

2. Verder word daarop gewys dat die Kerk sy „,voorbereiding” in die ou verbond het en dat die apostels van Joodse afkoms was.

3. Die afwysing van Jesus van Nasaret as die Messias deur 'n groot deel van die Jode word genoem. Dit word egter in aansluiting by Rom. 11:28 en 29 beklemtoon dat hulle by God geliefd is.

4. In die slotgedeelte word gewys op die praktiese konsekwensies van die voorafgaande: wedersydse agting, teologiese samewerking, afwysing van die ou vooroordeel van die „kollektiewe skuld" van die Jode aan Christus se kruisiging.

5. Die stuk eindig met die opmerking dat die Kerk met die profete en Paulus wag op daardie dag „wanneer al die volke God met een stem sal aanroep en eendragtig sal dien.

Dit is opmerklik dat die term "Joodse volk" nie in die verslag gebruik word nie. Daar is nêrens oor die huidige Jode as volk gepraat nie. As rede hiervoor is aangegee dat die Kerk enige politieke implikasies wou vermy. Dit mag so wees, gesien die reaksie wat die Verklaring by Rooms Katolieke Arabiere ontlok het. Terselfdertyd is enige identifikasie van die teenswoordige Jode met die ou volk Israel egter vermy. Dit pas Rome want dit lyk nie of hierdie Kerk enige ander kontinuïteit tussen Israel en die Jode van vandag wil erken nie as net 'n blote religieus-historiese nie. Die verkiesende handeling van God word vermy.

77) Bv. by E. Flesseman-van Leer, De Kerk en het Joodse Volk in Nederlands Theologisch Tijdschrift, 22ste Jaargang, 2de aflewering, Des. 1967, bl. 117v en H. Berkhoff, Israel as a Theological Problem in the ChristIan Church, J.E.S., Vol. VI, No. 3, bl. 332. 
Die Verklaring se opmerking dat die Kerk 'n ,geestelike gebondenheid met die nakomelinge van Abraham" het, is gladnie duidelik as daaraan toegevoeg word dat die Kerk sy ,voorbereiding" in die ou verbond het nie. Dit bring Israel, die ou verbond en die Ou Testament in gedrang. Israel en die ou verbond bly dan nog steeds vir Rome praeperatio, praesignatio, figura van die Kerk en die Ou Testament die dokument daarvan. Daar is dan geen kontinuïteit tussen Israel en die Kerk nie. Die novus populus Dei of die novus Israel het Israel volkome vervang.

Dit blyk ook dat hierdie Verklaring die besondere eskatologiese verwagting van Rom. 11:28 en 29 vir Israel nie met Paulus deel nie. Dit is vervang met 'n verwagting vir ,alle volke”.

Israel beklee dus geen besondere posisie by Rome nie - nóg negatief nóg positief.

\section{DIE VERHOUDING „KERK EN ISRAEL” BY DIE WERELD- RAAD VAN KERKE:}

Die Wêreldraad van Kerke het hom vanaf sy eerste vergadering, Amsterdam (1948) met die Kerk se verhouding tot Israel besig gehou. Hierdie vergadering het 'n Report on the Christian approach to the Jews aangeneem waarin onder andere die volgende verklaar is: „In the design of God Israel has a unique position. It was with Israel whom God made his covenant by the call of Abraham. It was Israel to whom God revealed His name . . sent His prophets . . . promised the coming of His Messiah. By the history of Israel God prepared the manger in which the fullness of time He put the Redeemer of all mankind, Jesus Christ. The Church has received this spiritual heritage from Israel and is therefore in honour bound to render it back in the light of the cross. We have, therefore, in humble conviction to proclaim to the Jews: The Messiah for whom you wait has come ${ }^{78}$ ).

Die wêreldraad van Kerke het dit nog as die taak van sy lidkerke gesien om „mission work among the Jews" te doen.

Op die vergadering van Evanston (1954) was dit duidelik dat daar skerp verskille rondom Israel onder die lidkerke is. Die tema van die vergadering was "Christ - the Hope of the World". 'n Poging van enkele Europese afgevaardigdes om 'n paragraaf oor "The Hope of Israel" in die verslag op te neem, is nie net afgewys nie maar die vergadering het dit selfs afgestem dat in die voorwoord van die verslag melding van hierdie mosie gemaak sou word! Die rede vir hierdie houding van die meeste afgevaardigdes

78) Aanhaling van hierdie rapport by Göte Hedenquist, The Church and the Jewish People, London 1954, bl. 201-205. 
was van politieke aard. Tydens die vergadering is 'n skrywe ontvang van 'n Libanese staatsman, Charles Malik, waarin hy die vergadering vermaan het om nie 'n verklaring oor ,a lasting revelance of the Jewish people" te maak nie omdat al die beloftes wat aan die ou Israel gemaak is, vervul is in Christus ${ }^{79}$ ).

Die vergaderings van New Dehli (1961) en Uppsala (1968) kon in hierdie verband niks verder vorder as die veroordeling van anti-Semitisme nie.

Die saak het egter die aandag bly geniet van die Committee on the Church and the Jews. Saam met die Faith and Order Commission is die studie voortgesit en in die vergadering van die Faith and Order Commission gehou te Bristol (1967) is 'n rapport aanvaar oor The Church and the Jewish People ${ }^{\mathrm{s}}$ ).

Hierdie rapport is 'n belangrike dokument met die oog op die peiling van die jongste denke in die Wêreldraad van Kerke oor Israel. Ons bepaal ons hoofsaaklik by die 3de ("Theological Considerations") en 4de (,,The Church and her witness") hoofstukke.

a) Onder die ,Theological Considerations" gaan dit hoofsaaklik oor die plek van Israel in die heilswerk van God. „God formed Israel," maar God het nie net vir Israel in die oog nie, maar ,all mankind" - ,in dealing with Israel God had in view the other nations; this was the road by which He came to them". Daarom ,verteenwoordig" Israel in sy uitverkiesing ,the others". Die gedagte van "representation" is van die grootste belang vir die opstellers van die rapport. So vervul Christus as die ,representative" van Israel sy taak tot gehoorsaamheid. Maar ook die apostels en die eerste dissipels as "representatives" in wie "Gods purpose for the whole of Israel is manisfested and confirmed”. Israel is meer as slegs ,voorbereiding" van die Kerk want die Kerk is "Israel having come to recognize God in Christ, together with the Gentiles who are engraved into Israel". Alleen in hierdie opsig is die Kerk "the continuation of Israel". Die aksent val op hierdie "continuation" en nie soos by die Tweede Vatikaanse Konsilie op die Kerk as die "nuwe Israel" of die „nuwe volk van God" nie.

b) Wat die huidige status van Israel betref le hierdie rapport 'n hegter band tussen die ou Israel en die huidige Israel (of die Joodse volk van vandag): "We are convinced that the Jewish people still have a significance of their own for the Church", want,... by their very existence ... they make it manifest that God has not abandoned them". En in hierdie opsig is hulle

79) Vergelyk Berkhof, a.w., bl. 332.

80) Vir hierdie raport, vergelyk New Directions in Faith and Order, Geneva 1968, bl. 69-80, (Quoted: New Directions). 
„a living and visible sign of God's faithfulness to men". Verder word bely dat God se "promise and calling will ultimately prevail so as to bring them to salvation". Daarmee is die eskatologiese gesigspunt gegee wat ook oor Israel na alle volke uitgaan.

Die vraag of die huidige Joodse volk ook in die verlengstuk van Israel lê, het vir die opstellers van die rapport probleme meegebring. Sommige was oortuig dat dit onmoontlik is om te praat van die „continued election" van die Joodse volk naas die Kerk. Alleen die Kerk is die "continuation of Israel as the people of God", want uitverkiesing en roeping ",are solely in Christ, and are to be grasped in faith". Albei Kerk (wat uit Jode en heidene bestaan) en die huidige Joodse volk kan nie uitverkore wees nie want dan is ,die liggaam van Christus" (dit is Sy volk) verdeeld.

Die ander groep wou nie uitgaan van die beeld van die „kerk as liggaam van Christus" nie, maar wil as uitgangspunt die begrip „volk van God" neem. Die Kerk en die Joodse volk word dan so onder 'n gemeenskaplike noemer gebring sodat albei, Kerk en Joodse volk uitverkies en volk van God is. Die een volk van God is dan na Christus in twee verdeel: die een deel van Sy volk glo, die ander deel het Christus verwerp maar bly ,in a special sense beloved by God". Die uitverkiesing word dus hier nie aan die geloof nie maar aan die barmhartigheid van God gebind! Die geloof as komponent van die verkiesing verval. Die gevolg is dat die "present-day Jews - religious or not - are still Israel".

Dit lyk asof hierdie tweede gedagterigting tog in die rapport as geheel oorheersend is. Dit pas natuurlik veel beter in die koers wat deur sommige teoloë van die Wêreldraad van Kerke ingeslaan word. Hulle wil naamlik die begrip „ecumenism enlarge ... to embrace not only Christians of varying persuasions . . . but Jews as well". „Ekumene" moet dan 'n sekere „extra-Christian meaning" kry wat dan moet bestaan in ,a spirit of cooperation and good will among all men whatever their theological or religious presuppositions". Die nuwe begrip „ekumene” sal dan die geleentheid bied vir ,a genuine dialoque encounter" met die Iodedom as nie-Christelike godsdiens ${ }^{81}$ ).

c) Dit is - aldus genoemde rapport - die Kerk se taak om in woord en daad die liefde van God in Jesus Christus aan alle mense te betuig. Maar hoe doen 'n mens dit teenoor die Jode? Die antwoord lui dat dit duidelik geword het in die Kerk se ontmoeting met die nie-Christelike godsdienste dat 'n paar dinge

81) Vergelyk A. T. Davies, The Jews in an Ecumenical context: $A$. Critique in J.E.S. Vol. V, No. 3, bl. $489 \mathrm{v}$. 
nodig is: „real openness" en nie 'n ,arrogant or paternalistic attitude" nie. Die lewe en denke van die nie-gelowige moet verstaan word om die getuienis van God se liefde in sy situasie te bring. Daarom is dit vir hierdie rapport duidelik dat die ou alternatiewe: "mission or dialoque" nie meer ter sake kan wees nie. Die getuienis van die Kerk oor sy geloof teenoor Israel sal dikwels eerder in "service" as in „explicit words" moet bestaan.

Dit kom weer eens in die rapport uit dat daar verskille oor hierdie "hoe" van die getuienis aan Israel onder die opstellers was - verskille wat gebaseer is op die verskillende ekklesiologiese uitgangspunte. As die Kerk ,liggaam van Christus” is, dan is die Jode buite soos ander nie-gelowiges en dan is hulle saam met die heidene voorwerp van die kerk se sending-taak.

Aan die anderkant: as die Kerk primêr begryp word as die "volk van God" dan is dit „moontlik" om die Kerk en die Jode as ,Een volk van God" te sien, wat tydelik van mekaar geskei is maar met die belofte dat hulle uiteindelik een sal word. In hierdie geval moet die Kerk se houding dan anders wees as sy houding tot ander mense „who do not believe in Christ!" Dit moet dan gesoek word ,in terms of ecumenical engagement in order to heal the breach than of missionary witness in which she hopes for conversion ${ }^{82}$ ).

d) Hierdie opmerking dat „ecumenical engagement" nodig is "to heal the breach" (tussen die dele van die een volk van God) is die konklusie van die sogenaamde "skisma"-teologie wat op die ekklesiologiese uitgangspunt gebou is dat die Kerk primêr „volk van God" is en nie "liggaam van Christus" nie.

Dit is nodig dat ons ook hierdie "skisma"-teologie nader sal bekyk, want dit lyk asof dit die uiteindelike oplossing vir die verhouding „Kerk en Israel” vir die Wêreldraad van Kerke gaan wees.

In die rapport van die eerste vergadering van die Wêreldraad van Kerke te Amsterdam het ons gesien dat die lidkerke "mission work among the Jews" moet doen. „Sending" en „evangelisasie" van Israel moes egter spoedig plek maak vir „dialoog” of "gesprek" met Israel. Maar as dit uitgangspunt is dat die Kerk "liggaam van Christus" is en die aksent dus moet val op die geloof in Jesus Christus en op die uitverkiesing alleen in Christus, dan is die Jode buitestaanders en moet die telos, van dic dialoog uiteindelik „conversion”, bekering van Israel wees. So 'n dialoog, sê die voorstaanders van hierdie teologie, is dan eintlik maar 'n monoloog wat uitgaan van die „superiority" van die Christendom en die minderwaardigheid van die Joodse Gods-

82) Ons kursivering. 
diens. Vir 'n „egte" gesprek tussen die Kerk en Judaisme is dit nodig dat die "Christian theology" Judaïsme moet ,understand and appreciate ... a a genuine biblical religion in its own right $^{\text {(3)}}$. Daar is dan blykbaar twee "genuine biblical religions": Judaĩsme en die Christendom, of soos hierdie mense dit self stel: twee „chismatic sections”. Hierdie skisma tussen Judaĩsme en Kerk is dan die „parent and prototype of all subsequent schisms in Christian history"84). En hierdie laasgenoemde skisma's (Ortodokse Kerk, Rooms Kotalieke Kerk en Protestantse Kerk) kan nie effektiéf opgehef word as die eerste "skisma", dié tussen die Kerk en die Judaĩsme, nie geheel is nie. Die ,structure must be set right before the spirit can be renewed ${ }^{85}$ ).

Die gesprek word dus voortgesit, maar dan as ,an ecumenical approach to the Jews", as 'n gesprek tussen twee "genuine biblical" godsdienste, wat as gevolg van die oer-,,skisma", twee "chismatic sections" van een en dieselfde volk van God is. Dan word Israel "de bakermat van de oecumene" en kan ,de Kerk haar oecumenisch karakter niet ten volle beleven" sonder Israel $\left.n \mathrm{e}^{88}\right)$.

e) Daar is nogal ooreenkoms tussen hierdie beskouing oor die verhouding van „Kerk en Israel" met die siening van 'n aantal Joodse geleerdes uit die meer resente tyd oor die verhouding "Israel en Kerk".

Streiker ${ }^{87}$ ) behandel die beskouing van enkele Joodse geleerdes aan die hand van ' $n$ boek van Hans Joachim Schoeps, The Jewish-Christian Argument: A History of Theologies in Conflict"88).

Volgens Schoeps is daar vir die gesprek tussen Israel en die Kerk 'n ,communicating body" nodig wat moet bestaan uit mense wat die waarheid van hulle godsdiens nie met „credal dogmas" staaf nie maar in hulle eie lewens. In hierdie gees, sê hy, was dit dan ook vir Rosenzweig moontlik om toe te gee wat geen Jood vroeër bereid was om te doen nie naamlik "that not ore of the nations of the world comes to the father except through Jesus Christ". Die Kerk vervul dan Israel se sending na die wêreld. Die Kerk moet egter nie probeer om Israel te bekeer nie want, sê hy, God is reeds met hulle. Op hierdie basis moet Israel die Kerk dan erken as ,a devinely revealed religion”.

83) A. T. Davies, a.w., bl. 503 (Ons kursivering).

84) A. T. Davies, a.w., bl. 503.

85) A. T. Davies, a.w., bl. 503 (Ons kursivering).

86) Vergelyk A. de Kuiper, a.w., bl. 40.

87) Lowell Streiker, The Modern Jewish-Christian Dialoque in J.E.S., Vol. 2,1965 , bl. $179-188$.

88) Hierdie boek het in 1937 verskyn, is verban onder die Nazies en her- 
Die vraag is of Israel nie dan maar moet oorgaan na die Kerk nie, gesien in die lig dat die Kerk aanspraak maak daarop dat hy die vervulling van Israel is? Hierop het Martin Buber geantwoord: "No, because the world is not yet redeemed". Buber is bereid om toe te laat vir soiets soos die Kerk se leer oor die inkarnasie, maar die hoop op ,consummation in the future points unconditionally, to the beyond at every moment of passing time: God transcendents absolutely all of his manifistations".

Schoeps wil die Kerk erken as die weg van God tot redding van die heidene buite Israel (al moet hy die Kerk verwerp vir sy ,wanopvattings oor die verbond en die wet"). Sy eie geloof is dus reg, maar só ook die getuienis van die Kerk. In die einde van die tyd sal die twee verbonde, die Oue en die Nuwe, een verbond word. Tot dan het elkeen, Israel en Kerk sy eie geheimenis. Die Kerk moet egter, sonder om sy geheimenis te verwerp dit is die geloof dat Jesus die Messias is - ook 'n weg vind om die Godsdiens van Israel sy eie waarde, betekenis en reg toe te ken.

Dit is duidelik, sê Streiker, dat op hierdie wyse die "gesprek" tussen Kerk en Israel nooit "sending" kan wees nie. Dit moe. die ,basic ground and rule for dialoque" wees.

f) Kritiese opmerkings:

i. Ten regte stel Lekkerkerker ${ }^{89}$ ) dat die knelpunt van die teologie van Israel in die eksegetiese en dogmatiese sektor geleë is.

ii. Die volgende dogmatiese aspekte is ter sake:

(a) Ons het dit in die ekklesiologie van die „skisma"-teologie te doen met 'n ekklesiologie wat losgemaak is van die Christologie en ook van die pneumatologie. Die geloof in Jesus Christus en die Kerk as Sy liggaam, word in hierdie denke uitgesny.

(b) Die leer van die uitverkiesing kom in gedrang. By Barth het ons gehoor dat die geloof die „komponent" van die uitverkiesing is. Wat is die uitverkiesing sonder die geloof in Jesus Christus? Wie is die God wat uitverkies? Uitverkiesing sonder geloof in Jesus Christus in Wie ons uitverkies is (Ef. 1:4), is 'n abstraksie!

(c) Dit behoef geen betoog dat die Bybel nie 'n ,genuine biblical religion" sonder geloof in Jesus Christus ken nie.

(d) Daar is ook vrae rondom die sogenaamde "skisma" tussen „Judaĩsme” en „Kerk". Kan 'n mens werklik die „,skisma” tussen Kerk en Israel op éen lyn stel met die van 1054 tussen die Kerk van die Ooste en die Kerk van die Weste of dié van die sestiende eeu tussen Rome en Reformasie? Die laasgenoemde twee „skis-

89) A. F. N. Lekkerkerker, Israël tussen Zending en Oecumene, in Kerk en Theologie, 16de Jaargang No. 1, Jun. 1965, bl. 54. 
ma's" het binne die Kerk voorgekom. Tussen hulle en die sogenaamde "skisma" tussen Kerk en Israel is daar geen verband nie. Die woord "skisma" word gewoontlik gebruik om 'n ,skeuring" of "verdeeldheid" binne die eenheid van die gemeente wat deur Jesus Christus in aansyn geroep is, aan te dui (byvoorbeeld 1 Kor. (1-4) $)^{\mathbf{s}}$ ). Dit was hoofsaaklik ook die betekenis van die woord by die Patres ${ }^{91}$ ). Johannes gebruik ,skisma" wel ter aanduiding van "verdeeldheid" wat onder die Jode ontstaan het rondom die "herkoms" (7:43), ,dade” (9:16-23) en „woorde (10:9) van Jesus ${ }^{92}$ ). Hierdie „skisma" sentreer rondom Jesus, rondom die waarheidsvraag. Hier gaap die afgrond (skisma) tussen geloof en ongeloof en nie dié tussen geloof en geloof nie. Christus bring self hierdie verdeeldheid (diamerismos - Luk. 12:51).

Die gebruik van "skisma" ten opsigte van Kerk en Israel as die oer voorbeeld van alle latere skismata wat binne die Kerk van Jesus Christus ontstaan het, is geforseerd en hou nie rekening met die bybelse gebruik van die woord nie. Daar is meer op die spel as gewone „struktuur” verskille.

(e) Om van 'n ,,ekumeniese verhouding tussen Kerk en Israel” te praat is "uiteraard hachelijk" ${ }^{93}$ ). Dit sou immers tot die konklusie kon lei dat Christus netso vreemd aan die Kerk as aan Israel is en dat albei dele van die volk van God eers vir Christus aan die einde van die tye sal leer ken. Die gemeente van Jesus Christus is egter reeds die eskatologiese Israel, die nuwe skepping van God wat sy Heer ken al is sy Heer ook nog die Heer wat (weer) kom.

(f) Die woord "gesprek" met Israel word bedenklik as ons begin lees van Judaĩsme as ,a genuine biblical religion”, of van 'n ,gesprek" met die "Islam" of met „die godsdienste van die wêreld!" Is hulle in hierdie gesprekke miskien gelyke partye? Indien wel, wat het die begrip „ekumene” dan nog met die Kerk van Christus te doen? Anders: as die Kerk Christusbelydende Kerk wil wees en bly, kan dit dan iets anders doen as om duidelik "Nee" te sê vir die synkretisme wat in so 'n betekenisuitbreiding van die begrip ,ekumene" reeds opgesluit lê?

Die waarskuwing van Rengstorf ${ }^{94}$ ) teen die gebruik van die benaming "Joodse broeders" deur Christene, is myns insiens 'n tydige waarskuwing, want daarin lê die gedagte opgesluit dat dit maar net 'n kwessie van gewilligheid aan albei kante is dan is die probleem opgelos. Dit sal vir albei partye goed wees as hulle sou toegee dat hulle nie broers is in die sin dat hulle albei

90) Vergelyk A. F. N. Lekkerkerker, a.w., bl. 54.

91) Vergelyk ThWNT VII, bl. 965.

92) Vergelyk ThWNT, VI, bl. 964.

93) A. F. N. Lekkerkerker, a.w., bl. 54. 
aan dieselfde volk van God behoort nie. Hulle kan immers alleen in die verwagting lewe dat hulle een dag broers sal word "through the Messiah of God whom they have in common".

Selfs van Joodse kant is daar 'n waarskuwing. Prof. R. J. Zwi Werblowski het daarop gewys dat "dialogitis" een van die nuwe siektes van ons eeu is en dat die mense wat die vurigste voorstaanders van 'n gesprek tussen Kerk en Israel is, dikwels twyfelagtige verteenwoordigers van hulle eie geloofsoortuigings is. Hy beweer dat die voorstaanders vir die gesprek met die Kerk, van Joodse kant, nie kom uit die ortodokse-Joodse sektor nie maar uit die liberale kringe ${ }^{93}$ ).

\section{DIE VERHOUDING KERK EN ISRAEL BY DIE LUTHERAN WORLD FEDERATION:}

Die „Lutheran World Federation" se „Department of World Mission" het vanaf 26 April tot 2 Mei 1964 'n beraad gehou oor "The Church and the Jewish People" ${ }^{96}$ ) te Logumkloster, Denemarke.

Volgens die rapport van die beraad ${ }^{97}$ ) lê die problematiek van die verhouding Kerk en Joodse volk in die volgende twee sake:

1. Die Joodse volk en die Kerk deel die begin van God se reddingswerk in die geskiedenis; vir albei getuig die Ou Testament oor hierdie tydperk; albei glo in die God van Abraham, Isak en Jakob. Hulle verskil egter ten opsigte van die geloof in Jesus van Nasaret as die Messias.

2. Die Joodse volk hou vol dat hulle 'n nasie, 'n volk is alhoewel by hulle vir eeue reeds die voorvereistes vir volk-wees ontbreek soos byvoorbeeld een taal, een kultuur, een vaderland.

Hierby het twee verdere sake gekom naamlik anti-semitisme en die Kerk se herinterpretasie van sy sending wat die vraag na vore bring of daar 'n spesiale sending vir die Jode moet wees en indien wel, waaruit dit moet bestaan.

Wat Kerk en Israel betref huldig die verslag die volgende standpunt:

1. Die benaming Israel mag alleen soos in die Bybel gebruik word: dit wil sê in die eerste plek as uitdrukking van God se vrye genade aan Abraham en sy nageslag, die volk van die ou

94) K. H. Rengstorf, a.w., bl. 81.

95) Vergelyk ds. S. Gerrsen, Geen Dialogitis in Kerk en Israel, 20ste Jaargang no. 12 , bl.

96) Die voordragte en verslag van hierdie konferensie is saamgevat in Christians, Jews, and the Mission of the Church, Publication of the Lutheran World Federation 1964.

97) A.w., bl. 144-149. 
verbond, aan wie God Sy wil openbaar het en Sy versoening beloof het tot heil van die nasies; as benaming van die volk van die nuwe verbond wat bestaan uit Jode én heidene wat deur die versoening in Christus mede-erfgename van die beloftes geword het.

2. Die vervulling van die beloftes in Jesus Christus, die Messias en die aanvaarding daarvan deur ' $n$ deel van die Jode het aanleiding gegee tot 'n ,division ... . which has placed ,old' Israel outside the ,new' ". Hierdie breuk sal geheel word wanneer „die hele Israel" (Rom. 11:26) Jesus van Nasaret aanvaar as die Messias. Daarom moet hulle wat deel gekry het aan die erfenis dankbaar hulle verantwoordelikheid ten opsigte van die „oorspronklike erfgename" aanvaar.

Wat „sending' en "gesprek" betref kom in die verslag die volgende uit:

1. Die Kerk is die "liggaam van die Here" in hierdie wêreld, geroep om „die groot dade van God" aan alle mense te verkondig en om hulle in die naam van Christus te smeek om hulle met God te laat versoen (2 Kor. 5:20).

2. Daarom moet die Kerk sendingwerk doen om die boodskap van die versoening aan alle mense te bring.

3. As lid van "Sy liggaam", is elke lid van die Kerk 'n "gestuurde" en is van toepassing op die hele verhouding van die gelowige tot die wêreld deur: sy geloof te bely ( 1 Petr. 3:15), na ander te luister, te probeer verstaan en die laste van sy medemens te help dra.

4. Om voor die Jode te getuig, is deel van die opdrag van die Kerk. Hierdie getuienis moet gebring word in die gewone werksaamhede van die gemeente wat bestaan in die getuienis van elke afsonderlike lid van die gemeente. Waar daar egter Joodse gemeenskappe is wat buite bereik van die gemeente lewe moet sending organisasies in die lewe geroep word om die evangelie daar te gaan afkondig.

5. Dit is die Christen se verantwoordelikheid om die Joodse volk en hulle geloof te verstaan. Daarvoor is die "gesprek" dienlik. Uitgangspunt sal egter nie die gelykstelling van die twee godsdienste wees nie en kan die Christelike getuienis nie uitsluit nie.

\section{OPMERKING:}

In hierdie rapport het ons dit met 'n ander ekklesiologie te doen as by die Wêreldraad van Kerke. Die Kerk is die „liggaam van Christus". God se uitverkiesing is uitverkiesing in Christus. Die geloof in Christus bly die komponent van die uitverkiesing. 
By alle kontinuiteit is dit duidelik dat dit "gebroke" kontinuiteit is as gevolg van Israel se verwerping van die Messias. Daarom staan Israel buite die Kerk en kan hy alleen deel van die Kerk word as hy Jesus as Messias aanvaar. Die Kerk is die volk van die nuwe verbond en dus die Israel van God. Daarom moet die Kerk Israel evangeliseer en kan hy hom daarin van die gesprek bedien. Die ,gesprek" vervang egter nie die „evangelisasie" nie.

\section{E. „KERK EN ISRAEL” BY DIE NEDERDUITSCH HERVORM- DE KERK VAN AFRIKA:}

In Die Kerkwet van die Nederduitsch Hervormde Kerk van Afrika word Die Apostolaat van die Kerk soos volg omskrywe:

„As Christus-belydende Kerk in die wêreld, vervul die Kerk sy apostoliese opdrag in gehoorsaamheid aan die bevel van Jesus Christus: ,Gaan dan heen, maak dissipels van al die nasies en doop hulle in die Naam van die Vader, die Seun en die Heilige Gees; en leer hulle om alles te onderhou wat Ek julle beveel het', Mattheus 28:19, deur die voortdurende arbeid aan die kerstening en reformasie van die volk en deur die evangelisering van Jood en heiden, sodat alle volke die verlossing wat in Jesus Christus is, kan verkry met die ewige heerlikheid"'s ).

In Hoofstuk IV, onder die Bepaling vir die Apostolaat, word onder die opskrif Die bring van die Evangelie buite die Kerk, 'n nadere omskrywing gegee:

„Die Kerk is hom bewus van die besondere verantwoordelik heid teenoor die volk en teenoor alle volke en mense wat vreemd staan teenoor die evangelie van Jesus Christus. Daarom ag die Ferk dit sy dure plig om die evangelie te bring aan:

(a) alle buitekerklikes;

(b) die volk van Israel;

(c) die volke wat oorwegend heidens is"99).

Volgens die bepaling vir die Raad vir die Arbeid onder Israel is dit die werk van hierdie Raad „om planne te beraam om die evangelie tot die volk van Israel te bring" ${ }^{100}$ ).

Hieruit kom die volgende sake met betrekking tot Israel en die apostolaat van die Kerk na vore:

1. Israel van die verharding word as volk erken.

2. Israel tel onder die „volke en mense wat vreemd staan teenoor die evangelie van Jesus Christus”, en dus buite die Kerk staan.

98) Art. IX (Ons kursivering).

99) Die Kerkwet, Art. 42 (Ons kursivering).

100) Die Kerkwet, Art. 46 (Ons kursivering). 
3. Jood en heiden moet dus ,evangeliseer" word.

4. Maar in sy evangelisasie van die „Jood" wil die Kerk onderskeid maak tussen die „bring van die evangelie aan Israel" en dieselfde werk ten opsigte van die „buitekerklikes” en die „heidense volkere".

5. Dit is egter ook duidelik dat die volk Israel wat vreemd staan teenoor die evangelie en wat gevolglik ge-evangeliseer moet word, vir die Kerk bepaalde probleme na vore laat kom. Vandaar die opdrag van Die Raad vir die Arbeid onder Israel „om planne te beraam om die evangelie tot die volk van Israel te bring".

\section{OPMERKINGS:}

\section{DIE APOSTOLAAT VAN DIE KERK:}

Die Kerk handel oor die „evangelisering” van die Jode of die bring van die evangelie aan die Jode onder die apostolaat. Wat word met "die apostolaat van die Kerk" bedoel? Ons wys slegs op enkele trekke.

By Barth het ons gehoor dat dit die „Zeugendienst" van die Kerk is om aan die hele wêreld (ook aan die hele Israel)! "Gottes siegreicher Erbarmen" te verkondig en die wêreld tot geloof op te roep. Dit is in kort die apostolaat van die Kerk wat gefundeer is op die opdrag van die Heer van die Kerk self. Artikel IX van Die Kerkwet verwys dan ook na Mtt. 28:19: Gaan dan heen, maak dissipels van alle nasies ...". Dit staan ook in ander woorde geskrywe: Die Kerk moet Sy getuies wees tot aan die uiterste van die aarde (Hand. 1:8); die sprekers van die ,groot dade van God" (Hand. 2:11); die ,verkondigers van die deugde van Christus" (1 Petr. 2:9). Dit moet die Kerk in sy hele bestaan en woord in die wêreld en vir die wêreld wees. En omdat dit die opdrag aan die hele Kerk is, is dit ook die werk van elke lidmaat van die Kerk.

Die Kerk is die ,apostel", die uitgestuurde van die Heer van die Kerk. Van Ruler ${ }^{101}$ ) wys egter daarop dat die aposolaat 'n omvorming van die "schaliach-figuur uit het Joodse bodenrecht" is. Die uitgestuurde "representeer" sy sender sodat die sender in die uitgestuurde ,present" is. In die apostolaat van die Kerk is die uitsturende Heer van die Kerk dus "present” in Sy uitgestuurde. Hy (God) is die eintlike subjek en agens. Die apostolaat is dus altyd ook meer as opdrag (,dat leidde gemakkelijk tot een ongeestelijke evangelisatorisch of sociaal activisme van die Kerk”) en ook meer as getuie-wees (,dat anthropoligiseert de zaak te veel"). Die apostolaat is die wese van die Kerk. Die Kerk

101) A.A. van Ruler, Bijzonder en Algemeen Ambt, Nijkerk 1952, bl. 28-29. 
is „praedestinatiaans" tot „iets" gestel, naamlik om ,instrument” in God se hand te wees ${ }^{102}$ ). Die Kerk word deur God gebruik. God is in die apostolaat van die Kerk reddend, verlossend besig met die wêreld. Die apostolaat van die Kerk het dus 'n onvervreembare „pneumatologiese” aspek. Wanneer dit nie só verstaan word nie, kan dit hoogstens misverstaan word.

Hierdie insig is van die grootste betekenis vir die doelstelling en metode van alle praktiese apostoliese arbeid. Van Ruler stel dit so: „De Kerk, de christen, de zending is nooit meer dan het karretje, het vehicilum, waarop het Woord van God - het geschreven, het kanonieke, het israëlitische woord - zich voortbeweeg van de eene mens naar de andere, van de eene tijd naar de andere, van het ene volk naar het andere. De Bijbel wordt daar telkens weer neergelegd en dan moeten wij hem - principieel gezien - aan zijn eigen lot, d.wz. aan de Geest, overlaten en afwachten, wat er met de Bijbel gebeurt en wat die andere mens, die andere tijd, dat andere volk met de Bijbel doet" ${ }^{103}$ ).

Die Kerk kan dus niks meer doen in sy apostolaat as om die Bybel, maar dan die hele Bybel, Ou én Nuwe Testament (met die aanstoot wat hy gee as geskrewe, kanonieke en IsraeliWoord!) te vervoer na die buitekerklikes, Israel en die heidense volke nie. Hy mag nie minder doen nie (want dan is hy nie meer Kerk van Christus nie), maar hy kan en mag ook nie meer wil doen nie (dit sal userperende vergrype wees aan dit wat aan God behoort!) Dit is immers nie die Kerk nie, maar $\mathrm{Hy}$, die Heilige Gees wat mense bekeer en dissipels van Jesus Christus maak!

Dit mag veral in die Kerk se arbeid onder Israel nie vergeet word nie. Die Kerk moet aanhou om die hele Bybel uit te dra na hierdie volk toe en geduldig wag op die vervulling van Sy belofte wat op Sy tyd en op Sy manier sal geskied. Dit is waar wat ons by Barth gehoor het dat Israel die evangelie ,prinsipieel, a priori en dus mensliker wys gesproke, sonder moontlikheid van revisie verwerp het". Maar nou lyk dit aan die anderkant nie reg dat die Kerk nou met Barth ook sal sê: hier is niks meer „zu missionieren" nie! Hier kan ons slegs wag op daardie gebeurtenis wanneer God direk sal ingryp en Israel bekeer nie. God se weg met alle mense en volke wat vreemd staan teenoor die evangelie, is Sy weg deur die apostolaat van die Kerk, dit wil sê Sy weg langs die weg van menslike getuienis. Dit is ook die weg wat in die Bybel met Israel gevolg is as ons let op die prediking van Petrus op Pinkster of die van Stefanus of die

102) A. A. van Ruler, Theologie van het Apostolaat, Nijkerk 1954, bl. 21.

103) A. A. van Ruler, Theologie van het Apostolaat, bl. 24. 
gewoonte van Paulus om altyd by die synagoge te begin. Dit sal ook goed wees as ons altyd maar weer hierdie eerste verkondiging van die Kerk in gedagte hou. Hulle prediking was „Missions-oder Bekehrungspredikt" wat gerig was op die bekering van Israel. Israel moet glo in ",die Here en Christus" in wie daar vir hulle bekering en vergifnis van sondes in (Hand. 2:37-39). Daar bestaan in sommige teologiese kringe vandag blykbaar die gedagte dat ons nie meer so "grof" oor Israel mag oordeel soos byvoorbeeld Stefanus nie ${ }^{104}$ ). Maar word daar dan nog erns gemaak met Israel?

Die Nederduitsch Hervormde Kerk van Afrika maak in die uitvoering van die apostolaat onderskeid tussen die verskillende „Adressaten" van die evangelie: Israel word onderskei van die buitekerklikes (wat die evangelie gehoor en daarop belydend geantwoord het, maar sedertdien weer daarvan in meerdere of mindere mate vervreem het) en die heidense volke (wat die evangelie nog moet hoor). Israel het Jesus nog nooit as Christus en Here bely nie. Tog wil die Kerk hom ook nie sondermeer by die heidene reken nie want daar is by alle gebrokenheid tog kontinuiteit tussen Israel en die Kerk ${ }^{105}$ ).

Dit is opmerklik dat die Nederduitsch Hervormde Kerk van Afrika nie soos die Nederlandse Hervormde Kerk van ,gesprek met Israel” praat nie ${ }^{106}$ ), maar van „evangelisasie”, „bring van die evangelie" aan hierdie volk. Dit is myns insiens 'n verstandige verbetering van die ,gespreksgedagte”. „Gesprek” het 'n modewoord geword en vertoon reeds duidelike tekens van ontaarding soos ons hierbo onder die Wêreldraad van Kerke aangedui het.

Die begrip ,evangelisasie" sluit alle menslike willekeur in die Kerk se taak ten opsigte van Israel vooraf uit. In die apostolaat van die Kerk kan dit immers om niks anders as die Bybel gaan nie - om daardie Bybel wat "die krip" is waarin die Christus van God lê. Die hele Bybel is hierdie krip. Daarom moet die hele Bybel tot Israel gebring word. Of anders gestel: die apostolaat van die Kerk ken net een bron van sy verkondiging of getuienis van Jesus Christus en ook net een reël vir die geloof: die Bybel en dan weer eens: die hele Bybel.

Die gevaar is groot dat in die ,gesprek" met Israel die eenheid van die Heilige Skrif uit die oog verloor kan word. Die standpunt kan ingeneem word (soos hierbo aangetoon) dat Kerk en Israel saam die Ou Testament besit en dat op grond van hier-

104) Vergelyk hieroor G. C. van Niftrik, Kroniek in Kerk en Theologie, Dertiende Jaargang, No. 2, April 1962, bl. 128.

165) Sien bl. hierbo.

106) Kerkorde van de Nederlandse Hervormde Kerk. Art. VIII. 
die gemeenskaplike besit 'n ,gesprek" gehou kan word tussen twee "genuine biblical religions" wie se verskille eers na die Ou Testament, buite die kanon van die Ou Testament, ontstaan het. Behalwe dat die eenheid van die Heilige Skrif só geskaad word, word ook die interpretasie van die Ou Testament aangetas. Die Kerk verstaan dit só dat die Ou Testament nie losgemaak van die Nuwe Testament werklik verstaan kan word nie soos die Nuwe Testaent ook nie sonder die Ou Testament gelees kan word nie. Barth stel dit baie sterk: die Ou Testament losgemaak van die vervulling in Jesus Christus, is ,eine judische Abstraktion $^{108}$ ). Die afgronde wat daar in die Ou Testament is, word alleen duidelik vir hulle wat die vervulling van die Ou Testament in Jesus Christus glo en bely ${ }^{\mathbf{1 0 8}}$ ).

Die Ou Testament, sonder sy vervulling in Jesus Christus, kan nie grond vir 'n ,gesprek" tussen Kerk en Israel onder die apostolaat van die Kerk wees nie.

'n „Gesprek” tussen Kerk en Israel kan waardevol wees, wanneer dit ,informasiegesprek" is. Informasie oor Israel is van die grootste belang vir die uitvoering van die apostolaat van die Kerk. As die Kerk die "karretjie" is wat die hele Bybel by Israel moet gaan aflewer, dan is dit nodig dat die Kerk (ook in elkeen van sy lidmate) die ,adres" sal ken. Die Kerk moet Israel ken. En dit is waar dat die Kerk nog baie by en oor Israel kan leer en ook moet leer. Dit is egter ook duidelik dat dit alles en nog meer hoogstens waardevolle hulpmiddels kan wees om die hele Kerk en al sy lidmate beter toe te rus vir die uitvoering van sy uiteindelike taak naamlik die apostolaat ten opsigte van Israel, die getuienis voor hierdie volk oor Jesus Christus en die oproep tot geloof in Hom. Hier sal die christen voluit Christen moet wees wat nie 'n oomblik sal huiwer om vir Israel te wys hoe die Ou Testament gelees moet word wanneer die ,bedekking by die lesing van die Ou Testaent opgelig" is ( 2 Kor. 3:14). Hier kan dit slegs om die eis om bekering en geloof gaan. Indien dit anders moet wees, sal ons "Israel” onder die apostolaat van cie Kerk, moet skraap.

107) KD 12, bl. 98. Só ook $O$. Weber in Grundlagen 1, bl. 341: „Die Nachfrage nach dem Verhältnis des altestamentlichen Wortes zum neutestamentlichen Heilsgeschehen ist kein willkürliches Unternehmen. sondern sie ist mit dem Glauben an den, der als der Messias Israels der Herr der Gemeinde und der Heiland der Welt ist, im Bereich der Kirche und ihrer Theologie durchaus sachgemäss und unabweisbaar". Op 'n ander plek weer: "Wir können von vornherein kein israelitisches Verältnis zum Alten Testament haben und daher auch kein israelf. tisches Verstehen dieses Buch versuchen wollen. Wir haben ein Verhältnıs zum Alten Testament, ein Verhältnis zum Gesetz und ein Verhăltnis zu Israel nur in Christus". Grundlagen 1,, bl. 332.

$\left.{ }_{108}\right)$ G. C. van Niftrik, Kroniek in Kerk en Theologie, Dertiende jaargang no. 1 , Jan. 1962 , bl. 50. 